Prepared in cooperation with the City of Wichita Falls, Texas

\title{
Assessment of Channel Changes, Models of Historical Floods and Effects of Backwater on Flood Stage, and Flood Mitigation Alternatives for the Wichita River at Wichita Falls, Texas
}

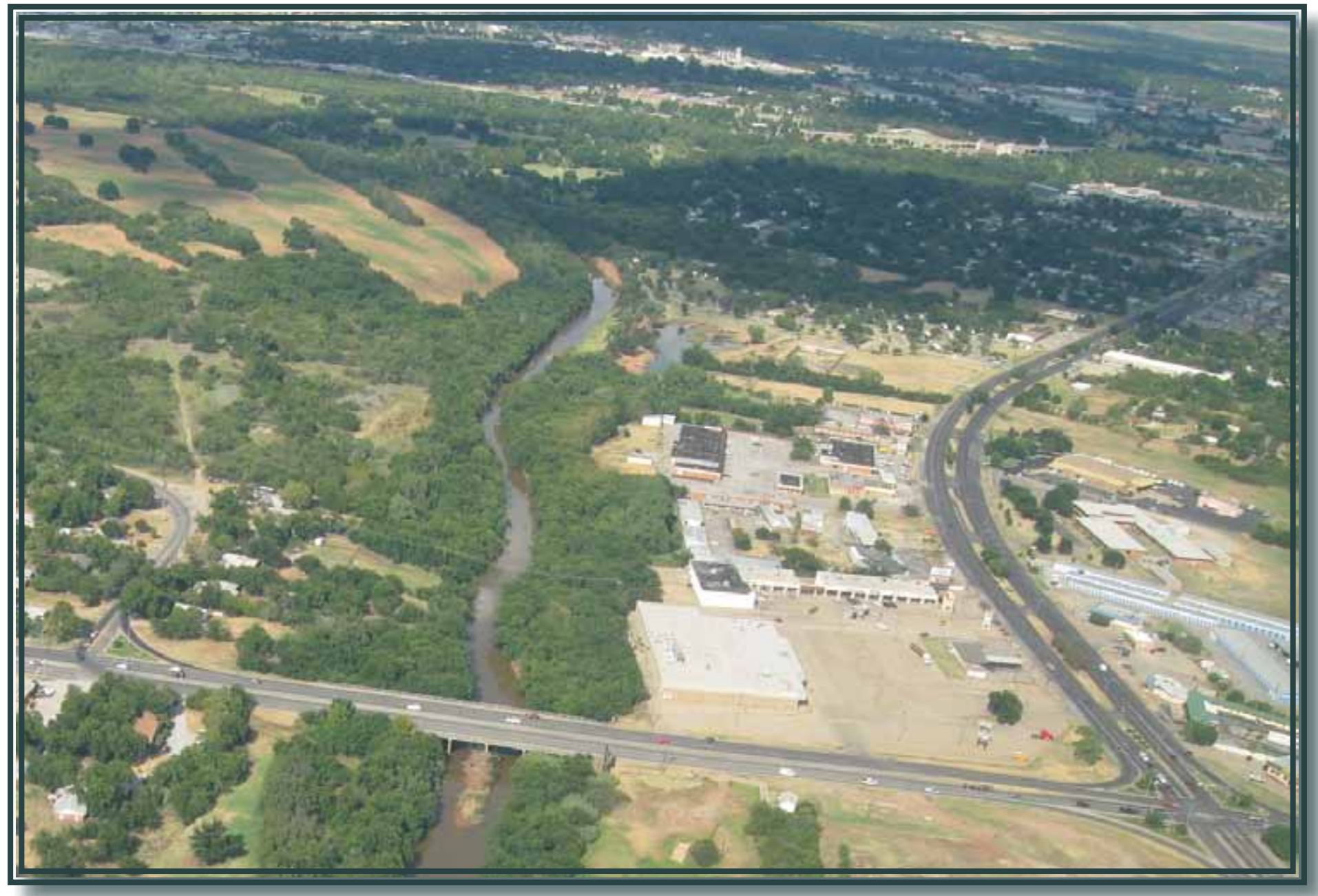

Scientific Investigations Report 2011-5175 
Front cover: Looking downstream from Loop 11 and U.S. Geological Survey streamflow-gaging station 07312500 Wichita River at Wichita Falls, Texas, August 23, 2010.

\section{Back cover:}

Top photograph, Looking upstream along Holliday Creek, August 23, 2010. The arrow indicates the location of U.S. Geological Survey streamflow-gaging station 07312610 Holliday Creek at Wichita Falls, Texas.

Bottom photograph, Former U.S. Geological Survey colleague David Holmes and author Karl Winters in flight over the Wichita River, August 23, 2010. 


\section{Assessment of Channel Changes, Models of Historical Floods and Effects of Backwater on Flood Stage, and Flood Mitigation Alternatives for the Wichita River at Wichita Falls, Texas}

By Karl E. Winters and Stanley Baldys III

Prepared in cooperation with the City of Wichita Falls, Texas

Scientific Investigations Report 2011-5175 


\section{U.S. Department of the Interior \\ KEN SALAZAR, Secretary \\ U.S. Geological Survey \\ Marcia K. McNutt, Director}

U.S. Geological Survey, Reston, Virginia: 2011

This and other USGS information products are available at http://store.usgs.gov/

U.S. Geological Survey

Box 25286, Denver Federal Center

Denver, C0 80225

To learn about the USGS and its information products visit http://www.usgs.gov/ 1-888-ASK-USGS

Any use of trade, product, or firm names is for descriptive purposes only and does not imply endorsement by the U.S. Government.

Although this report is in the public domain, permission must be secured from the individual copyright owners to reproduce any copyrighted materials contained within this report.

Suggested citation:

Winters, K.E., Baldys, Stanley, III, 2011, Assessment of channel changes, models of historical floods and effects of backwater on flood stage, and flood mitigation alternatives for the Wichita River at Wichita Falls, Texas:

U.S. Geological Survey Scientific Investigations Report 2011-5175, 28 p. 


\section{Contents}

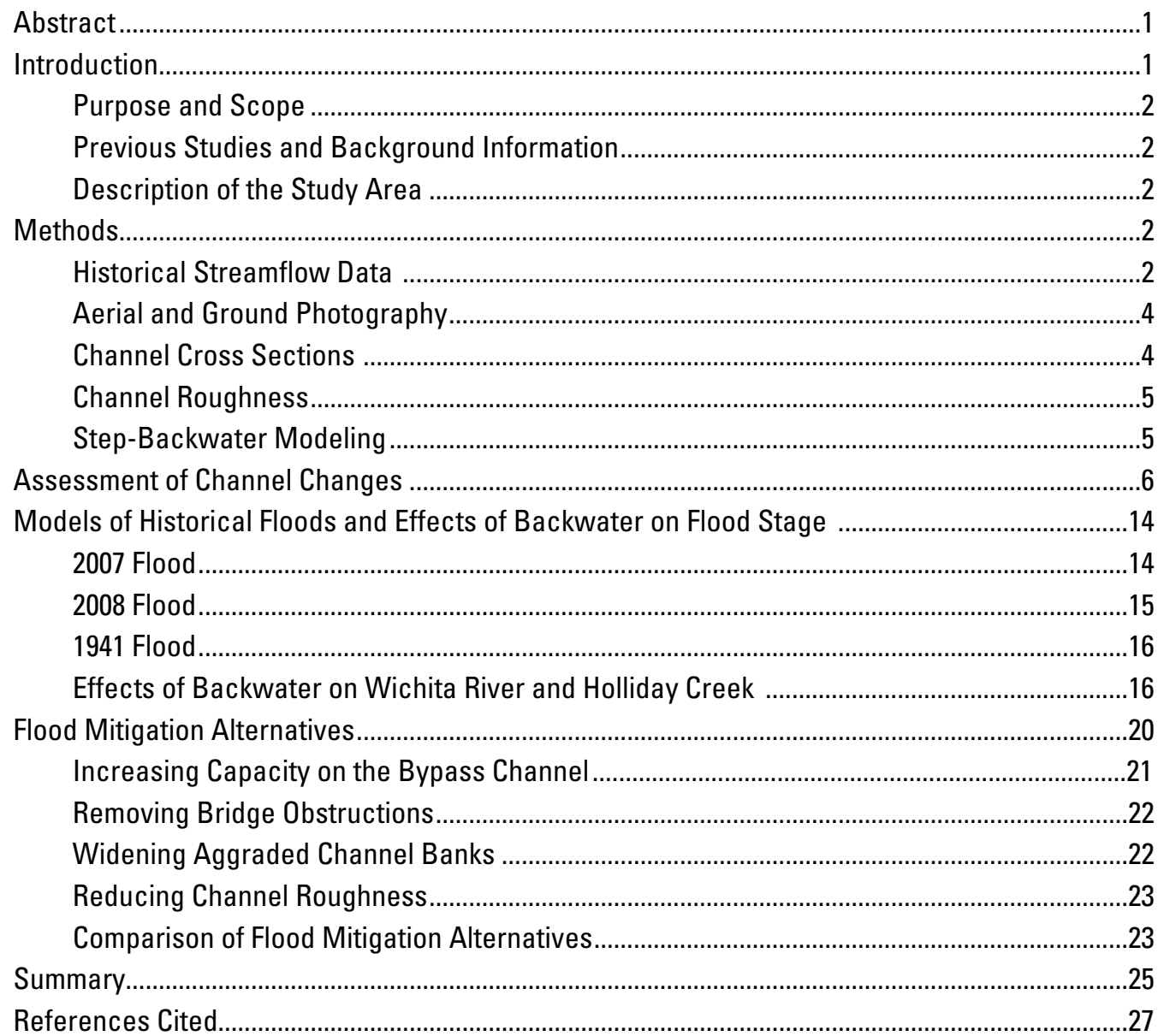

\section{Figures}

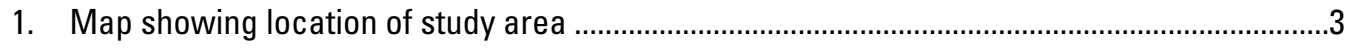

2. Photograph of staff gage operated by the City of Wichita Falls, Texas ....................................

3. Graph showing changes in the stage-discharge relation indicated by measurements at U.S. Geological Survey streamflow-gaging station 07312500 Wichita River at Wichita Falls, Texas (Loop 11 gage) ............................................................................

4. Graph showing mean velocities from measurements at U.S. Geological Survey streamflow-gaging station 07312500 Wichita River at Wichita Falls, Texas

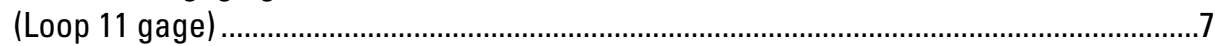

5. Graph showing annual peak discharges at U.S. Geological Survey streamflowgaging station 07312500 Wichita River at Wichita Falls, Texas (Loop 11 gage) ................8

6. Aerial photograph showing Scott Avenue and Martin Luther King Junior Boulevard bridges on the Wichita River, February 7, 1968.

7. Photographs of Wichita River looking downstream from Loop 11 in 1950, 1961, 1975, and 2009 at U.S. Geological Survey streamflow-gaging station 07312500 Wichita River at Wichita Falls, Texas 
8. Aerial photograph of Wichita River looking downstream from Loop 11, August 23, 2010, Wichita Falls, Texas.

9. Graph showing historical channel cross sections of the Wichita River at U.S. Geological Survey streamflow-gaging station 07312500 Wichita River at Wichita Falls, Texas, 1938-2009

10. Graph showing channel cross sections of the Wichita River between 0.9 and 2.6 miles downstream from Martin Luther King Junior Boulevard, Wichita Falls, Texas, 1986 and 2009.

11. Photograph of Wichita River obstructions $A$, on the right (south) bank at the downstream side of Scott Avenue bridge looking downstream and B, on the left bank at Martin Luther King Junior Boulevard bridge, looking downstream, February 23, 2009

12. Graph showing Wichita River cross sections from 1986 and 2009, and the obstruction on the right (south) bank at the downstream side of Scott Avenue bridge in Wichita Falls, Texas.

13. Graph showing Wichita River cross sections from 1986 and 2009 and the obstruction on the left (north) bank at the downstream side of the Martin Luther King Junior Boulevard bridge in Wichita Falls, Texas

14. Graph showing calibrated water-surface profile for the 2007 flood on the Wichita River at Wichita Falls, Texas.

15. Graph showing calibrated water-surface profile for the 2008 flood on the Wichita River at Wichita Falls, Texas...

16. Graph showing cross-section conveyance computed from 1991 Federal Emergency Management (FEMA) HEC-2 model (1991 FEMA) and 2009 U.S. Geological Survey HEC-RAS model (2009 USGS) at U.S. Geological Survey streamflow-gaging station 07312500 Wichita River at Wichita Falls, Texas (Loop 11 gage)

17. Graph showing calibrated water-surface profiles for the 2007 and 1941 floods on the Wichita River at Wichita Falls, Texas.

18. Graph showing stage hydrographs during A, January 2010, and B, July 2010 at U.S. Geological Survey streamflow-gaging stations 07312500 Wichita River at Wichita Falls, Texas (Loop 11 gage), 07312610 Holliday Creek at Wichita Falls, Tex. (Holliday Creek gage), and 07312700 Wichita River near Charlie, Tex. (Wichita River near Charlie, Tex., gage)

19. Graph showing water-surface profiles computed for various streamflow amounts in Holliday Creek, with no backwater from the Wichita River, Wichita Falls, Texas

20. Graph showing water-surface profiles computed for various streamflow amounts in Holliday Creek, with backwater caused by streamflow of 10,100 cubic feet per second in the Wichita River (the 2007 flood peak), Wichita Falls, Texas

21. Graph showing computed water-surface profiles for streamflow of 10,100 cubic feet per second (the 2007 flood peak) in the Wichita River, with backwater caused by various streamflow amounts in Holliday Creek, Wichita Falls, Texas

22. Graph showing computed water-surface profiles for streamflow of 10,100 cubic feet per second (the 2007 flood peak) in the Wichita River, with bypass channel cut deeper by 4 feet and 8 feet, Wichita Falls, Texas.

23. Graph showing computed water-surface profiles for streamflow of 10,100 cubic feet per second (the 2007 flood peak) in the Wichita River, with parts of the channel widened and obstructions near Scott Avenue and Martin Luther King Junior Boulevard bridges removed, Wichita Falls, Texas 
24. Photograph looking downstream from Loop 11 at the U.S. Geological Survey streamflow-gaging station 07312500 Wichita River at Wichita Falls, Texas, February 25, 2009

25. Graph showing reduction in Manning's roughness coefficient $(n)$ corresponding to a reduction in channel-bank and flood-plain vegetation, Wichita River at Wichita Falls, Texas.

26. Graph showing water-surface profiles computed for streamflow of 10,100 cubic feet per second (the 2007 flood) in the Wichita River, with vegetation reduced 20 and 50 percent on the channel banks and flood plain, Wichita Falls, Texas

\section{Tables}

1. Continuous streamflow records on Wichita River and Holliday Creek

2. Calibrated roughness coefficients for the Wichita River at U.S. Geological Survey streamflow-gaging station 07312500 Wichita River at Wichita Falls, Texas (Loop 11 gage)

3. Selected floods recorded at U.S. Geological Survey streamflow-gaging station 07312500 Wichita River at Wichita Falls, Texas (Loop 11 gage).

4. Peak stages at U.S. Geological Survey streamflow-gaging stations on Wichita River and Holliday Creek, north Texas, October 2009-September 2010

5. Computed water-surface elevations for 10,100 cubic feet per second (the peak discharge of the 2007 flood) on the Wichita River at Wichita Falls, Texas, for existing (2010) channel conditions and various flood-mitigation alternatives.

\section{Conversion Factors}

Inch/Pound to SI

\begin{tabular}{lcl}
\hline \multicolumn{1}{c}{ Multiply } & By & \multicolumn{1}{c}{ To obtain } \\
\hline $\begin{array}{l}\text { foot }(\mathrm{ft}) \\
\text { mile }(\mathrm{mi})\end{array}$ & Length & \\
\hline & 0.3048 & meter $(\mathrm{m})$ \\
& 1.609 & kilometer $(\mathrm{km})$ \\
\hline square mile $\left(\mathrm{mi}^{2}\right)$ & Area & \\
\hline & 2.590 & square kilometer $\left(\mathrm{km}^{2}\right)$ \\
\hline cubic foot $\left(\mathrm{ft}^{3}\right)$ & Volume & \\
\hline & 0.02832 & cubic meter $\left(\mathrm{m}^{3}\right)$ \\
\hline foot per second $(\mathrm{ft} / \mathrm{s})$ & Flow rate & \\
cubic foot per second $\left(\mathrm{ft}^{3} / \mathrm{s}\right)$ & 0.3048 & meter per second $(\mathrm{m} / \mathrm{s})$ \\
\hline
\end{tabular}

Vertical coordinate information is referenced to the North American Vertical Datum of 1988 (NAVD 88).

Horizontal coordinate information is referenced to the North American Datum of 1983 (NAD 83).

A water year is the 12-month period October 1 through September 30 designated by the calendar year in which it ends. 



\title{
Assessment of Channel Changes, Models of Historical Floods and Effects of Backwater on Flood Stage, and Flood Mitigation Alternatives for the Wichita River at Wichita Falls, Texas
}

\author{
By Karl E. Winters and Stanley Baldys III
}

\begin{abstract}
In cooperation with the City of Wichita Falls, the U.S. Geological Survey assessed channel changes on the Wichita River at Wichita Falls, Texas, and modeled historical floods to investigate possible causes and potential mitigation alternatives to higher flood stages in recent (2007 and 2008) floods. Extreme flooding occurred on the Wichita River on June 30, 2007, inundating 167 homes in Wichita Falls. Although a record flood stage was reached in June 2007, the peak discharge was much less than some historical floods at Wichita Falls. Streamflow and stage data from two gages on the Wichita River and one on Holliday Creek were used to assess the interaction of the two streams. Changes in the Wichita River channel were evaluated using historical aerial and ground photography, comparison of recent and historical cross sections, and comparison of channel roughness coefficients with those from earlier studies. The floods of 2007 and 2008 were modeled using a one-dimensional stepbackwater model. Calibrated channel roughness was larger for the 2007 flood compared to the 2008 flood, and the 2007 flood peaked about 4 feet higher than the 2008 flood. Calibration of the 1941 flood yielded a channel roughness coefficient (Manning's $n$ ) of 0.030 , which represents a fairly clean natural channel. The step-backwater model was also used to evaluate the following potential mitigation alternatives: (1) increasing the capacity of the bypass channel near River Road in Wichita Falls, Texas; (2) removal of obstructions near the Scott Avenue and Martin Luther King Junior Boulevard bridges in Wichita Falls, Texas; (3) widening of aggraded channel banks in the reach between Martin Luther King Junior Boulevard and River Road; and (4) reducing channel bank and overbank roughness. Reductions in water-surface elevations ranged from 0.1 foot to as much as 3.0 feet for the different mitigation alternatives. The effects of implementing a combination of different floodmitigation alternatives were not investigated.
\end{abstract}

\section{Introduction}

Continuous records of stage and discharge have been made at U.S. Geological Survey (USGS) streamflowgaging station 07312500 Wichita River at Wichita Falls, Tex. (hereinafter the Loop 11 gage) since 1938. Stage is the elevation of the water surface referenced to an arbitrary datum (Langbein and Isseri, 1960, p.10; Rantz and others, 1982, p. 23). Discharge measurements at the Loop 11 gage location have been made sporadically beginning in 1900 and routinely since 1938. A record stage (since at least 1938) of 24.40 feet (ft) with a peak discharge of 10,100 cubic feet per second $\left(\mathrm{ft}^{3} / \mathrm{s}\right)$ was recorded on June 30, 2007. On August 19, 2008, a flood stage of $20.51 \mathrm{ft}$ with a peak discharge of $6,940 \mathrm{ft}^{3} / \mathrm{s}$ was recorded at the Loop 11 gage. The extreme flooding on the Wichita River on June 30, 2007, inundated 167 homes in Wichita Falls, Tex. (Federal Emergency Management Agency, 2011). Understanding the causes for increased flood stages on the Wichita River in 2007 and 2008 floods compared to flood stages during floods of similar or smaller magnitude prior to 1972 is important to water resource managers in Texas. Accordingly, the USGS, in cooperation with the City of Wichita Falls, assessed channel changes on the Wichita River in Wichita Falls, and modeled historical floods to investigate possible causes and potential mitigation alternatives to reduce flood elevations such as those experienced in recent (2007 and 2008) floods.

Changes in channel conveyance, a measure of the carrying capacity of a channel (Chow, 1959), can affect the reliability of streamflow gaging records used to determine annual exceedance probabilities for floods such as the 1percent annual exceedance probability flood, commonly referred to as the 100-year flood (Holmes and Dinicola, 2010). The reliability of annual peak-streamflow data for the Loop 11 gage requires an understanding of the factors affecting stream stage on the Wichita River. Factors affecting stream stage include riparian vegetation, obstructions in the channel, 
and backwater. The term "backwater" commonly refers to the increase in water-surface elevation upstream from an obstruction. In addition to being caused by obstructions, backwater can also be caused by interactions between streams. For example, a relatively higher water-surface elevation in one stream can impede flow entering from the mouth of the other stream, resulting in backwater in the impeded stream (Missouri Department of Transportation, 2011). Flooding without backwater is described as headwater flooding, where an area becomes inundated directly by surface runoff from upland areas (U.S. Army Corps of Engineers, 1987).

\section{Purpose and Scope}

This report documents changes in the channel of the Wichita River in Wichita Falls, Tex., and describes the results of a step-backwater model developed for modeling historical floods on the Wichita River and flood-mitigation alternatives. The effects of backwater on flood stage were also modeled. Wichita River channel changes and flow conditions affecting the 2007 flood are emphasized. This report does not include hydrologic or hydraulic assessment of design floods, such as the 1-percent annual exceedance probability flood (100-year flood).

\section{Previous Studies and Background Information}

Streamflow records during 1938-2007 at the Loop 11 gage indicate seven or eight floods roughly similar (or greater) in magnitude than the $10,100 \mathrm{ft}^{3} / \mathrm{s}$ peak discharge of the 2007 flood. Although the peak discharges of floods prior to 2007 were of similar or greater magnitude compared to the 2007 flood, none of the floods since 1938 reached the stage of the 2007 flood.

In 1993, the Federal Emergency Management Agency (FEMA) published a Flood Insurance Rate Map for Wichita Falls. Cross sections for the hydraulic analyses were based on a 1986 photogrammetric survey (Koogle and Pouls Engineering, 1986). In 2000, FEMA revised the Flood Insurance Rate Map for the City of Wichita Falls using new computed flood profiles for the Wichita River (Federal Emergency Management Agency, 2000). In 2010, FEMA published a Flood Insurance Rate Map for Wichita County, Tex., using the same photogrammetric surveys and hydraulic analyses that were used to develop the 2000 Flood Insurance Rate Map for Wichita Falls (Federal Emergency Management Agency, 2010). Winters and others (2010) described reduced channel conveyance on the Wichita River at Wichita Falls, Texas, during 1900-2009.

Dams impounding Lake Kemp and Lake Diversion were completed on the Wichita River about 40 miles (mi) west and upstream from Wichita Falls in 1923 and 1922, respectively (Red River Authority of Texas, 2011) (fig. 1). Collier and others (1996, p. 85) note that "floods are a key element in the future management of dams. Without periodic high flows, some channels downstream from dams will aggrade with sediment or narrow with overgrown vegetation. Two or three flood-free decades may have been traded for more devastating floods in the future."

\section{Description of the Study Area}

The study area includes segments of the Wichita River and Holliday Creek in and near Wichita Falls. Wichita River drains from west to east, emptying into the Red River about 25 mi northeast of Wichita Falls in north-central Tex. (fig. 1). The Tanglewood subdivision of Wichita Falls, where many of the 167 homes flooded in June 2007 are located, is near the upstream end of the study area. The Loop 11 gage is about 2 mi downstream from the Tanglewood subdivision (fig. 1). The upstream end of the study reach is defined as where the FortWorth Denver Railroad crosses the Wichita River, upstream from the Tanglewood subdivision. The downstream end of the study reach is $1.9 \mathrm{mi}$ downstream from the confluence of the Wichita River and Holliday Creek (this segment of the Wichita River downstream from Holliday Creek was included to ensure a sound solution of the hydraulic model at the confluence of the Wichita River with Holliday Creek). Because flow from Holliday Creek can affect flood stages in the Wichita River upstream from Holliday Creek (fig. 1), Holliday Creek was modeled from Bridwell Street in Wichita Falls to the confluence of Holliday Creek with the Wichita River, about $3.7 \mathrm{mi}$ downstream from Bridwell Street. The Wichita River channel has wooded banks through much of the study reach. Holliday Creek has been highly altered and is a uniform, grass-lined, and trapezoidal channel. A manmade bypass channel near River Road in Wichita Falls (fig. 1) carries part of the flow in Wichita River during large floods. Flows in the bypass channel are governed primarily by the conveyance of its cross section at its entrance on the south bank of the Wichita River. The grass-lined bed of the bypass channel drops about $10 \mathrm{ft}$ over a short (about $350 \mathrm{feet}$ ) stream segment, about 1,600 ft downstream from where it diverts flow from the Wichita River.

\section{Methods}

\section{Historical Streamflow Data}

Data from three USGS streamflow-gaging stations were used to assess channel changes and evaluate flood-mitigation alternatives (table 1). In addition to data from the Loop 11 gage (the primary gage on the Wichita River for this report), data from two other USGS streamflow-gaging stations (fig. 1) were used in this study: USGS streamflowgaging station 07312610 Holliday Creek at Wichita Falls, Tex. (hereinafter the Holliday Creek gage), and USGS 


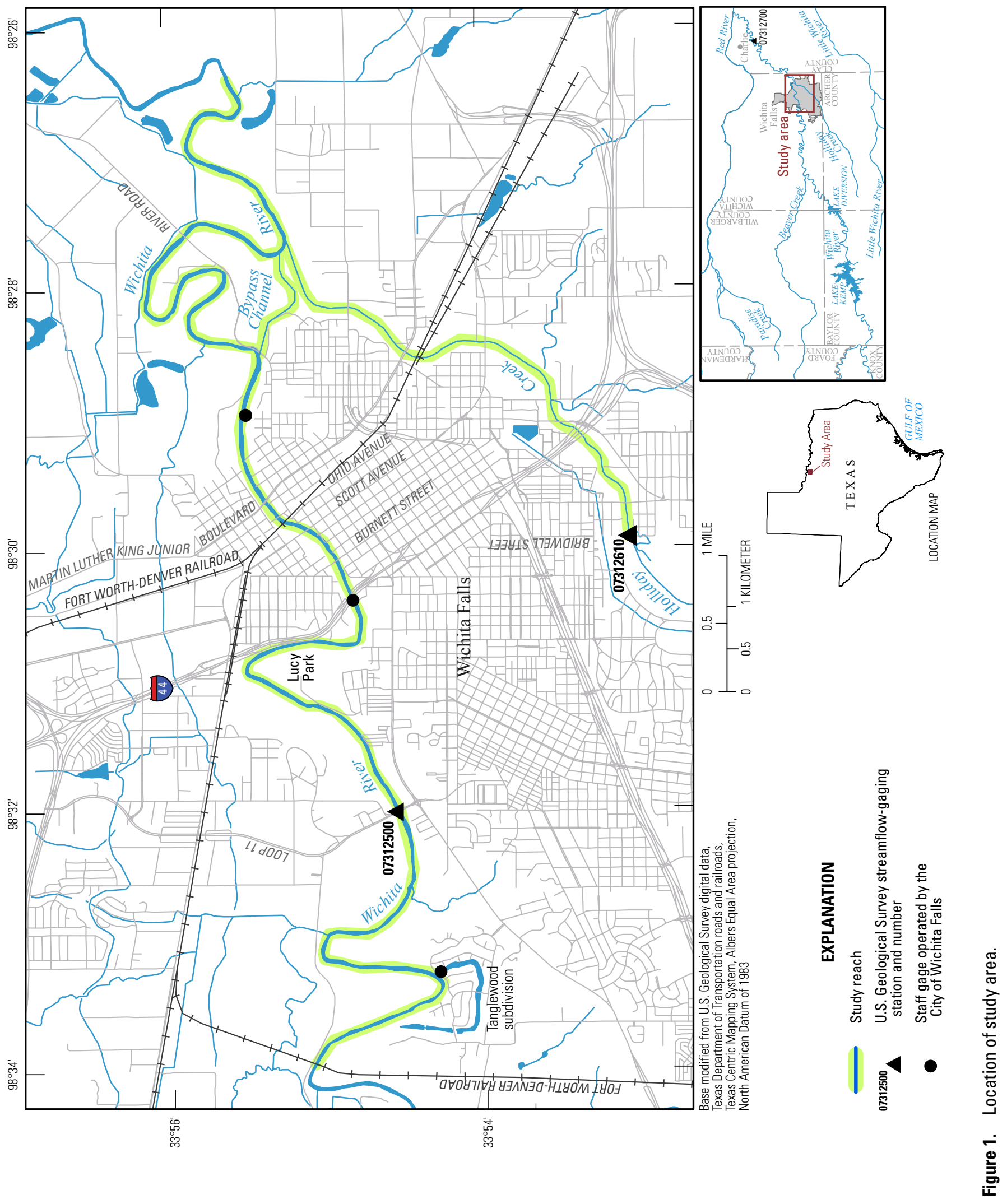


Table 1. Continuous streamflow records on Wichita River and Holliday Creek.

\begin{tabular}{|c|c|c|c|}
\hline $\begin{array}{l}\text { Station } \\
\text { number }\end{array}$ & $\begin{array}{l}\text { Station name (and } \\
\text { station identifier) }\end{array}$ & $\begin{array}{l}\text { Drainage } \\
\text { area, } \\
\text { (square } \\
\text { miles) }\end{array}$ & $\begin{array}{l}\text { Period of } \\
\text { record used }\end{array}$ \\
\hline 07312500 & $\begin{array}{l}\text { Wichita River at } \\
\text { Wichita Falls, Tex. } \\
\text { (Loop } 11 \text { gage) }\end{array}$ & $3,140^{1}$ & $\begin{array}{l}\text { March } 1938 \\
\text { through } \\
\text { September } 2010\end{array}$ \\
\hline 07312610 & $\begin{array}{l}\text { Holliday Creek at } \\
\text { Wichita Falls, } \\
\text { Tex. (Holliday } \\
\text { Creek gage) }\end{array}$ & 144 & $\begin{array}{l}\text { May } 2009 \\
\text { through } \\
\text { September } 2010\end{array}$ \\
\hline 07312700 & $\begin{array}{l}\text { Wichita River near } \\
\text { Charlie, Tex. } \\
\text { (Wichita River } \\
\text { near Charlie, } \\
\text { Tex. gage) }\end{array}$ & $3,439^{1}$ & $\begin{array}{l}\text { October } 1967 \\
\text { through } \\
\text { September } 2010\end{array}$ \\
\hline
\end{tabular}

${ }^{1} \mathrm{~A}$ total area of 2,205 square miles is upstream from Lake Diversion.

streamflow-gaging station 07312700 Wichita River near Charlie, Tex. (hereinafter the Wichita River near Charlie, Tex. gage). The Holliday Creek gage is located at Bridwell Street about 3.7 mi upstream from the mouth of Holliday Creek. About 16 mi northeast and downstream from the study area, streamflow is gaged at the Wichita River near Charlie, Tex., gage. Miscellaneous flood measurements made by the USGS between 1900 and 1936 at the location of the Loop 11 gage are included in the analyses. Analyses of streamflow data and hydrographs from the Loop 11 and Holliday Creek gages provide insight as to how stages on Holliday Creek and Wichita River affect one another. The Wichita River near Charlie, Tex., gage was used to assess the timing of flood hydrographs and to help evaluate the interaction of the Wichita River and Holliday Creek in Wichita Falls.

Measurements of stage and discharge were evaluated to help determine hydraulic changes that have occurred over time in the Wichita River channel. All discharge measurement data used for these analyses are stored in the USGS National Water Information System (NWIS) database (U.S. Geological Survey, 2010). Channel width and area for flood-discharge measurements were obtained from NWIS.

\section{Aerial and Ground Photography}

Aerial and ground photographs were analyzed to determine if an increase in vegetation in the channel or overbank in the reach of the river near the gage contributed to the elevated flood stages in 2007 and 2008 compared to historical flood stages for similar flood discharges. Aerial photographs taken during 1953-2008 (Tom Roehrig, Texas
Natural Resources Information System, written commun., 2009) were analyzed to determine if channel changes were visible in the reach downstream from Loop 11. Aerial photographs were examined for evidence of development in the flood plain and for general changes in the density of riparian vegetation. The scale of these photographs ranged from $1: 12,800$ to $1: 32,000$. In addition to aerial photographs, photographs taken from the ground were used for documenting channel changes. Since 1950, oblique (side looking) photographs of the Wichita River channel at Loop 11 have been taken periodically by personnel of the USGS. Oblique photographs of the channel at the Loop 11 gage provide valuable information about changes in the channel shape and vegetative cover.

\section{Channel Cross Sections}

During 1938-2010, more than 1,000 discharge measurements (U.S. Geological Survey, 2010) were made at the Loop 11 gage. These measurements provide a detailed history of channel cross sections in the Wichita River at Loop 11. These measurements typically include between 25 and 35 depth observations from which a detailed cross section is defined. Comparison of these cross sections over time provides insight to possible aggradation or degradation of the channel bed or banks.

In addition to historical cross sections measured at the Loop 11 gage during streamflow measurements, cross sections of the Wichita River in a reach of about $5 \mathrm{mi}$ from Loop 11 downstream to River Road (fig. 1) were surveyed by the USGS in 2009 using a total station and Real-Time Kinematic Global Positioning System (RTK-GPS) (Trimble, 2009). Cross sections for this reach of the Wichita River were compared to historical cross sections obtained from as-built plans for several bridges spanning the Wichita River from Loop 11 downstream to River Road (Loop 11, Interstate Highway 44, Burnett Street, Scott Avenue, Ohio Avenue, Martin Luther King Junior Boulevard, and River Road).

Changes in cross-section shape and vegetation density along a reach of the Wichita River channel in the study area were assessed by using historical streamflow measurements, aerial and ground photography, comparison of recent (2009) and historical cross sections and channel roughness coefficients (Manning's $n$; described in the Channel Roughness section) from 2009 with those used in a 1991 step-backwater model developed for the Federal Emergency Management Agency (FEMA). The 1991 step-backwater model was based on 1986 cross sections; the cross sections and Manning's $n$ values were documented in a HEC-2 model (HEC-2 is a step-backwater hydraulic model developed by the U.S. Army Corps of Engineers Hydrologic Engineering Center) prepared for FEMA (Cindy Mosier, Halff Associates, written commun., 2009), hereinafter referred to as the 1991 FEMA HEC-2 model. Cross sections for the 1991 FEMA HEC-2 model were obtained by photogrammetry in 1986 
(Koogle and Pouls Engineering, 1986; Federal Emergency Management Agency, 2000). The flood-plain cross-section and channel roughness data were obtained from the 1991 FEMA HEC-2 model input file.

\section{Channel Roughness}

All of the hydraulic models referenced in this report used Manning's coefficient, $n$, to represent the roughness of the channel bed, banks, and overbank. Manning's equation (Linsley and others, 1982) relates discharge to cross-section geometry, channel roughness, and channel slope and is defined as

$$
Q=A \times 1.486 / n \times R^{2 / 3} \times S^{1 / 2}
$$

where

$$
\begin{aligned}
Q & =\text { discharge, in cubic feet per second } \\
A & = \\
n & \text { cross-sectional area of flow, in square feet } \\
& \text { manning's } n \text { (coefficient of roughness) } \\
& \text { unitless } \\
R \quad= & \text { hydraulic radius, in feet } \\
S \quad= & \text { slope of the channel, in foot per foot }
\end{aligned}
$$

Manning's $n$ represents resistance to flow and is inversely proportional to flow velocity for a given depth. Manning's $n$ can be computed when the discharge, channel slope, and cross-section properties (area and depth) are known. Typically, however, in practice Manning's $n$ is selected based on knowledge of field conditions (channel-bed material, density of riparian vegetation, channel uniformity), guidance from field handbooks (Arcement and Schneider, 1989; Barnes, 1967), and engineering judgment (Chow, 1959, p. 101). For this study, Manning's $n$ was determined by using stepbackwater modeling as described in the Step-Backwater Modeling section.

\section{Step-Backwater Modeling}

A one-dimensional, steady-state, step-backwater model (Davidian, 1984) was developed by the USGS to assess channel changes on the Wichita River within the study reach (fig. 1) to evaluate different flood-mitigation alternatives. Winters and others (2010) used a step-backwater model to determine channel roughness and conveyance properties of the Wichita River from the Loop 11 gage downstream to River Road. Step-backwater computations are used to compute water-surface profiles on the basis of energy losses caused by friction from the moving water being in contact with the streambed, and from the expansion or contraction of the channel cross section. Energy losses caused by friction are related to the roughness of the streambed material, but are greatly affected by the density of vegetation in the channel or on the flood plain (Linsley and others, 1982). Required data for the model include cross-section geometry, channel and flood-plain roughness (Manning's $n$ ), and boundary conditions, which included recorded peak stages at selected locations along the river and known or assumed initial stream stage or water-surface slope at the downstream end of the model. For this study, the water-surface elevation at the downstream end of the model was determined by using a normal depth (Chow, 1959) solution of Manning's equation (equation 1). Brunner (2010, p. 3-2) states that this approach is "common practice" and that "any error at the boundary will diminish as the computations proceed upstream." When the cross-section geometry, discharge, and boundary conditions are known, the model can also be used to solve for Manning's $n$.

The U.S. Army Corps of Engineers Hydrologic Engineering Center River Analysis System (HEC-RAS) model (Brunner, 2008; U.S. Army Corps of Engineers, 2010) was used by the USGS for the computation of historical flood profiles (Winters and others, 2010). The calibrated HEC-RAS model was then used to assess the effect of various potential flood-mitigation alternatives. Additionally, the step-backwater model was used to assess the potential extent of backwater during flooding at the confluence of Wichita River and Holliday Creek. Calibration of the step-backwater model was done by using peak-stage data at the Loop 11 gage and from three staff gages in the study reach. The City of Wichita Falls maintains a network of staff gages, including three in the Wichita River study reach (figs. 1 and 2). Readings of these staff gages by City of Wichita Falls employees were typically every 15 to 30 minutes during the 2007 and 2008 floods to ensure reasonable definition of the flood hydrograph (Davis Powell, City of Wichita Falls, written commun., 2010). Initial values of Manning's $n$ for the channel and overbank at each cross section were selected during the 2009 survey.

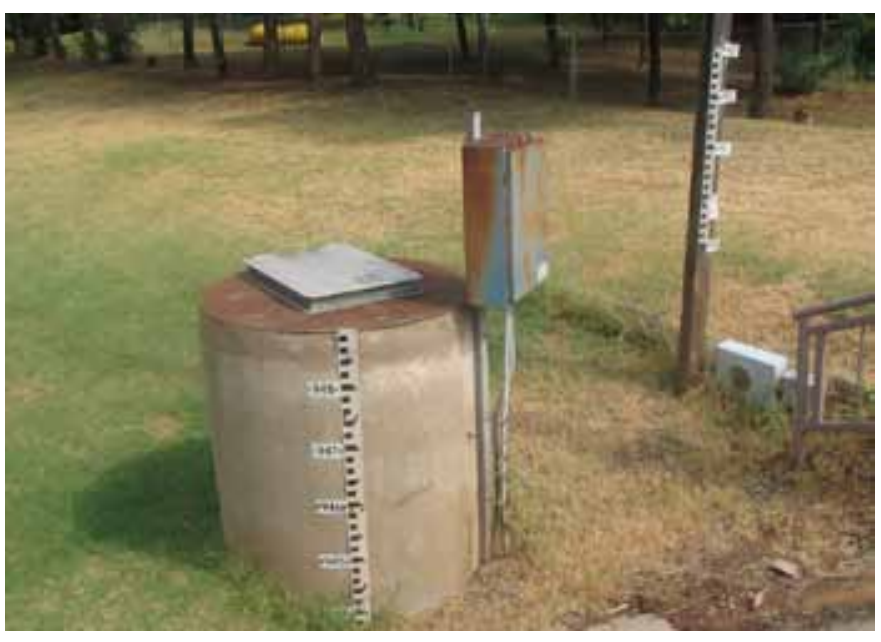

Figure 2. Staff gage operated by the City of Wichita Falls, Texas (photograph courtesy of Davis Powell, City of Wichita Falls). 
One-dimensional step-backwater models require separate values of Manning's $n$ for the channel and the flood plain at each cross section (Davidian, 1984). Calibration of the channel and flood-plain (overbank) roughness is typically handled in this manner: (1) the channel roughness is first calibrated by using known stage and discharge for a flood contained within the channel; (2) flood-plain (overbank) roughness is calibrated to known stage and discharge for a higher (overbank) flood by using the channel roughness from the first step. Normally, this approach works well; however, if the channel roughness varies with depth, the distribution of roughness across the flood plain (channel compared to overbank) might not be optimal. This problem arises because the real distribution of flow across the cross section is generally not known. An approach to solving this problem is to set limits for the channel and overbank values of Manning's $n$ (that is, the smallest and largest roughness coefficients expected for observed channel and overbank flow conditions). Field references with example photographs of stream channels and flood plains with calibrated roughness coefficients (Arcement and Schneider, 1989; Barnes, 1967) were also used for guidance in setting limits for Manning's $n$ and evaluating calibrated values for Manning's $n$. The calibrated roughness coefficients for the 2007 and 2008 peak flood stages at the Loop 11 gage are shown in table 2, along with calibrated roughness coefficients from a flood in 1941 with a peak flood stage similar to that of the 2007 flood; the 1941 flood is used for comparison with the 2007-8 floods because the channel in 1941 was different compared to the channel during 2007 and 2008.

In addition to the Wichita River cross sections surveyed in 2009 by the USGS in the 5-mi reach between Loop 11 and River Road (which were used for the historical comparisons), cross sections were used for flood-mitigation modeling purposes upstream from the Loop 11 gage to the Fort WorthDenver Railroad crossing (fig. 1), and downstream from River Road to a point $1.9 \mathrm{mi}$ downstream from the confluence of Wichita River with Holliday Creek. Cross sections for these segments of Wichita River, as well as those for the $3.7-\mathrm{mi}$ reach of Holliday Creek, were extracted from 2-ft contours provided by the City of Wichita Falls and based on a Light Detection and Ranging (LiDAR) survey (Davis Powell, City of Wichita Falls, written commun., 2010). Brunner (2010, p. 3-6) states that cross-section spacing is a function of the stream size, slope, and the uniformity of the cross-section shape. The maximum cross-section spacing used in the stepbackwater model developed by the USGS was $2,420 \mathrm{ft}$. The average spacing was $1,170 \mathrm{ft}$.

\section{Assessment of Channel Changes}

The more than 1,000 discharge measurements (U.S. Geological Survey, 2010) made at the Loop 11 gage during 1938-2010 indicate no substantial aggradation has occurred on the channel bed or banks near the Loop 11 gage. Aggradation, had it occurred, might have explained some of the increase in stage for the same volume of discharge (Heitmuller and Greene, 2009). Figure 3 depicts the relation between stage and discharge for discharge measurements made at the Loop 11 gage since 1938. Floods recorded in 2007 and 2008 at this gaging station, including the record flood of June 30, 2007, have reached higher flood stages compared to floods before 1972 (fig. 3). Comparing flood measurements made during 1938-71 with flood measurements made during 1972-2007, stages have been about 1 to $3 \mathrm{ft}$ higher since 1972 for floods that reached a stage of more than $18 \mathrm{ft}$ compared to stages measured for earlier floods of similar magnitude. Discharge measurements for stages of more than $18 \mathrm{ft}$ from 1938 to 2008 indicate a decrease in the measured mean velocity from about $3.5 \mathrm{ft} / \mathrm{s}$ in 1941 to about $2.0 \mathrm{ft} / \mathrm{s}$ in 2008 (fig. 4). This reduction in velocity was accompanied by an increase in stage to convey similar discharges through the system.

Table 2. Calibrated roughness coefficients for the Wichita River at U.S. Geological Survey streamflow-gaging station 07312500 Wichita River at Wichita Falls, Texas (Loop 11 gage).

[n, Manning's roughness coefficient]

\begin{tabular}{lccccc}
\hline Date & $\begin{array}{c}\text { Peak flood } \\
\text { stage } \\
\text { (feet) }\end{array}$ & $\begin{array}{c}\text { Peak discharge } \\
\text { (cubic feet per second) }\end{array}$ & Channel $\boldsymbol{n}$ & $\begin{array}{c}\text { Average } \\
\text { overbank } \boldsymbol{n}\end{array}$ & Maximum overbank $\boldsymbol{n}$ \\
\hline $10 / 03 / 1941$ & 24.00 & 17,800 & 0.030 & 0.064 & 0.077 \\
$6 / 30 / 2007$ & 24.40 & 10,100 & 0.048 & 0.18 & 0.22 \\
$8 / 19 / 2008$ & 20.51 & 6,940 & 0.041 & 0.18 & 0.22 \\
\hline
\end{tabular}

\footnotetext{
${ }^{1}$ Datum of gage is 924.53 feet above North American Vertical Datum of 1988.
} 


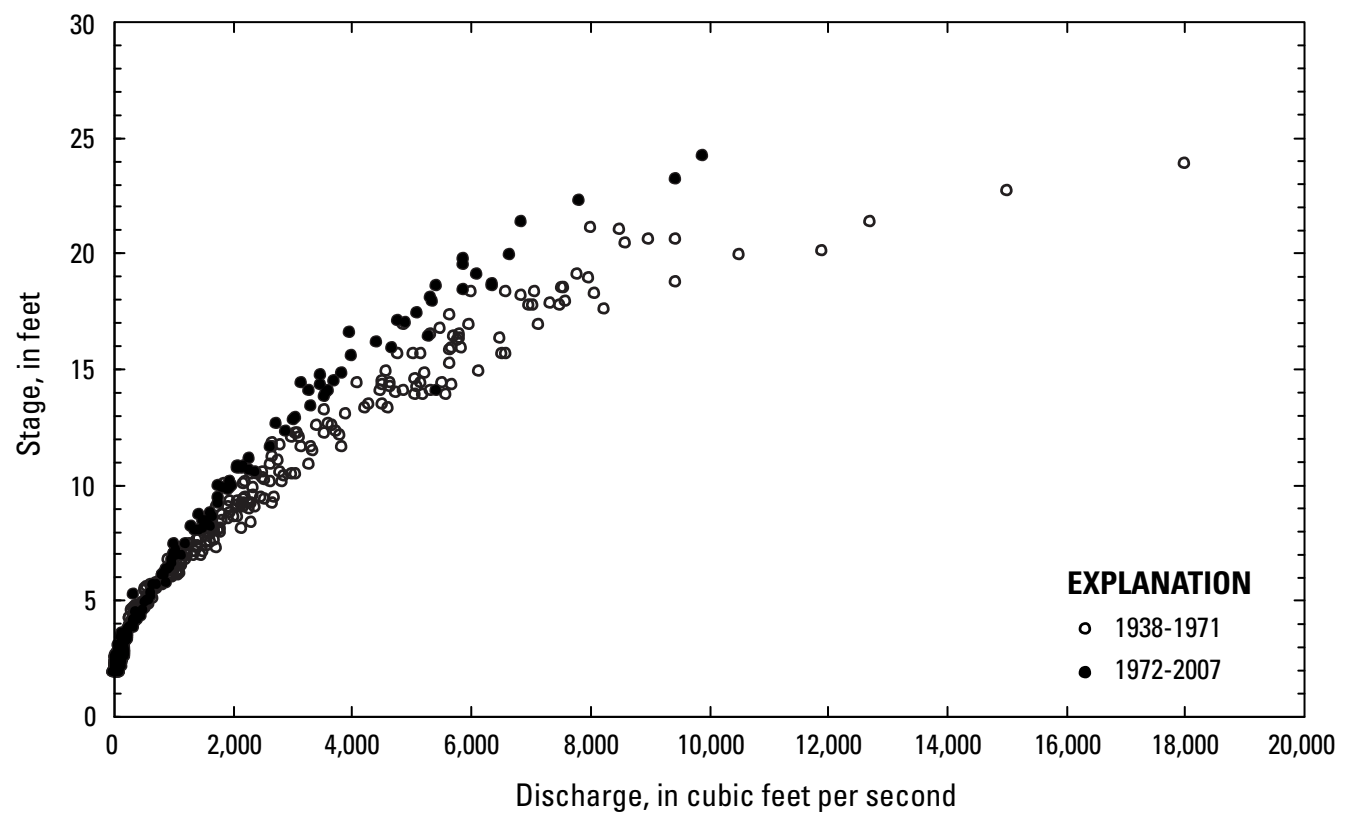

Figure 3. Changes in the stage-discharge relation indicated by measurements at U.S. Geological Survey streamflow-gaging station 07312500 Wichita River at Wichita Falls, Texas (Loop 11 gage).

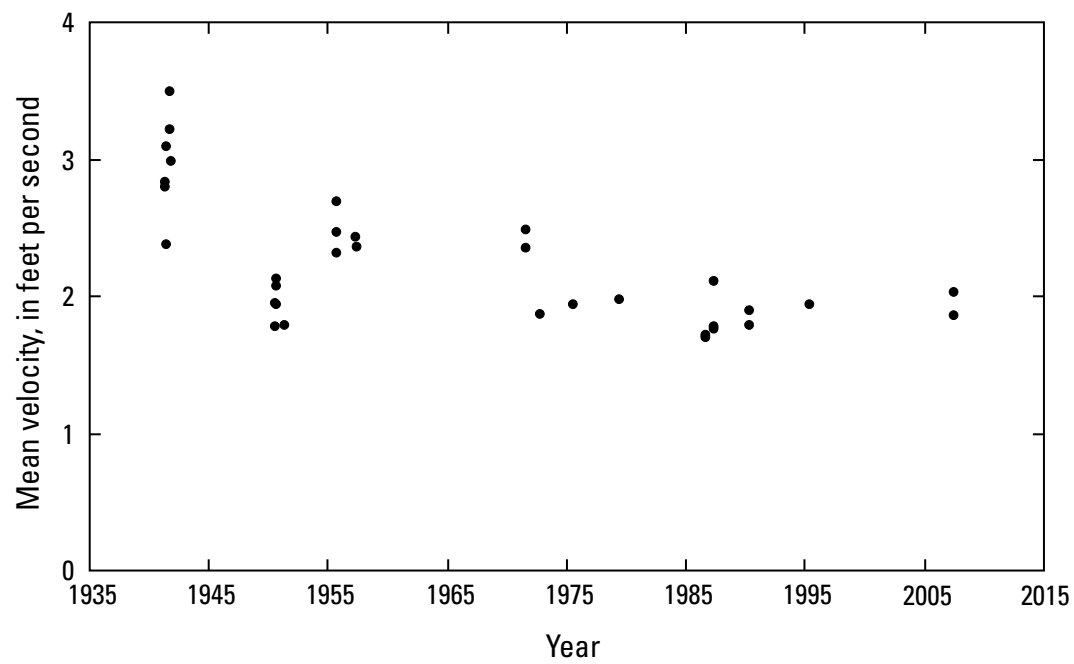

Figure 4. Mean velocities from measurements at U.S. Geological Survey streamflow-gaging station 07312500 Wichita River at Wichita Falls, Texas (Loop 11 gage). 
A record peak stage (since 1938 when stage records were first collected on a continuous basis) of $24.40 \mathrm{ft}$ at the Loop 11 gage with an associated peak discharge of 10,100 $\mathrm{ft}^{3} / \mathrm{s}$ was recorded on June 30, 2007 (table 3). On August 19,2008 , flood stages again peaked at more than $20 \mathrm{ft}$ at the Loop 11 gage, cresting at $20.51 \mathrm{ft}$ with an associated peak discharge of $6,940 \mathrm{ft}^{3} / \mathrm{s}$. Peak flood stages measured for the peak streamflows in 2007 and 2008 were higher compared to the peak flood stages measured for floods of similar magnitude in previous years. In 1955, 1957, and 1961, annual peak discharges ranging from 7,200 to 7,640 ft3/s were recorded with peak stages ranging from 17.93 to $18.27 \mathrm{ft}$. Although the annual peak discharges of 1955,1957 , and 1961 were all slightly larger compared to the August 2008 flood of 6,940 $\mathrm{ft}^{3} / \mathrm{s}$, the peak stages associated with the floods in 1955, 1957, and 1961 were 2.24 to $2.58 \mathrm{ft}$ lower compared to the peak stage of $20.51 \mathrm{ft}$ associated with the August 2008 flood.

Annual peak discharges measured between 1938 and 2008 and miscellaneous flood measurements between 1900 and 1936 at the location of the Loop 11 gage (fig. 5) indicate the magnitude of annual peak discharges has decreased since the Lake Kemp and Lake Diversion dams were completed on the Wichita River. The two largest annual peak discharges since these two reservoirs were built in the 1920s measured 15,500 and $17,800 \mathrm{ft}^{3} / \mathrm{s}$ in June and October of 1941, representing water years 1941 and 1942, respectively (a water year is the 12-month period from October 1 through September 30 and is designated by the calendar year in which it ends). Before 1941, miscellaneous flood measurements of $16,700,37,400$, and $50,000 \mathrm{ft}^{3} / \mathrm{s}$ were obtained at Loop 11 in 1900, 1901, and 1915, respectively. Prior to the June 2007 flood, which peaked at 10,100 $\mathrm{ft}^{3} / \mathrm{s}$, none of the annual peak
Table 3. Selected floods recorded at U.S. Geological Survey streamflow-gaging station 07312500 Wichita River at Wichita Falls, Texas (Loop 11 gage).

\begin{tabular}{lcc}
\hline \multicolumn{1}{c}{ Date } & Stage (feet) & $\begin{array}{c}\text { Peak discharge } \\
\text { (cubic feet per second) }\end{array}$ \\
\hline $10 / 03 / 1941$ & 24.00 & 17,800 \\
$9 / 27 / 1955$ & 18.12 & 7,200 \\
$5 / 3 / 1957$ & 18.27 & 7,200 \\
$3 / 19 / 1961$ & 17.93 & 7,640 \\
$6 / 30 / 2007$ & 24.40 & 10,100 \\
$8 / 19 / 2008$ & 20.51 & 6,940 \\
\hline
\end{tabular}

${ }^{1}$ Datum of gage is 924.53 feet above North American Vertical Datum of 1988.

discharges since 1943 had exceeded 10,000 ft $\mathrm{ft}^{3} / \mathrm{s}$, although five annual peak discharges exceeded 7,500 $\mathrm{ft}^{3} / \mathrm{s}$ (fig. 5).

The computed peak discharge $\left(10,100 \mathrm{ft}^{3} / \mathrm{s}\right)$ at the Loop 11 gage associated with the 2007 flood peak ( $24.40 \mathrm{ft}$ ) was based on a June 30, 2007, measured discharge of $9,900 \mathrm{ft}^{3} / \mathrm{s}$ at a stage of $24.22 \mathrm{ft}$.

Streamflow at the Wichita River near Charlie, Tex., gage peaked on July 4, 2007, with a peak discharge of $11,100 \mathrm{ft}^{3} / \mathrm{s}$. Although no gage was being operated on Holliday Creek in 2007, a USGS employee noted that while the Wichita River

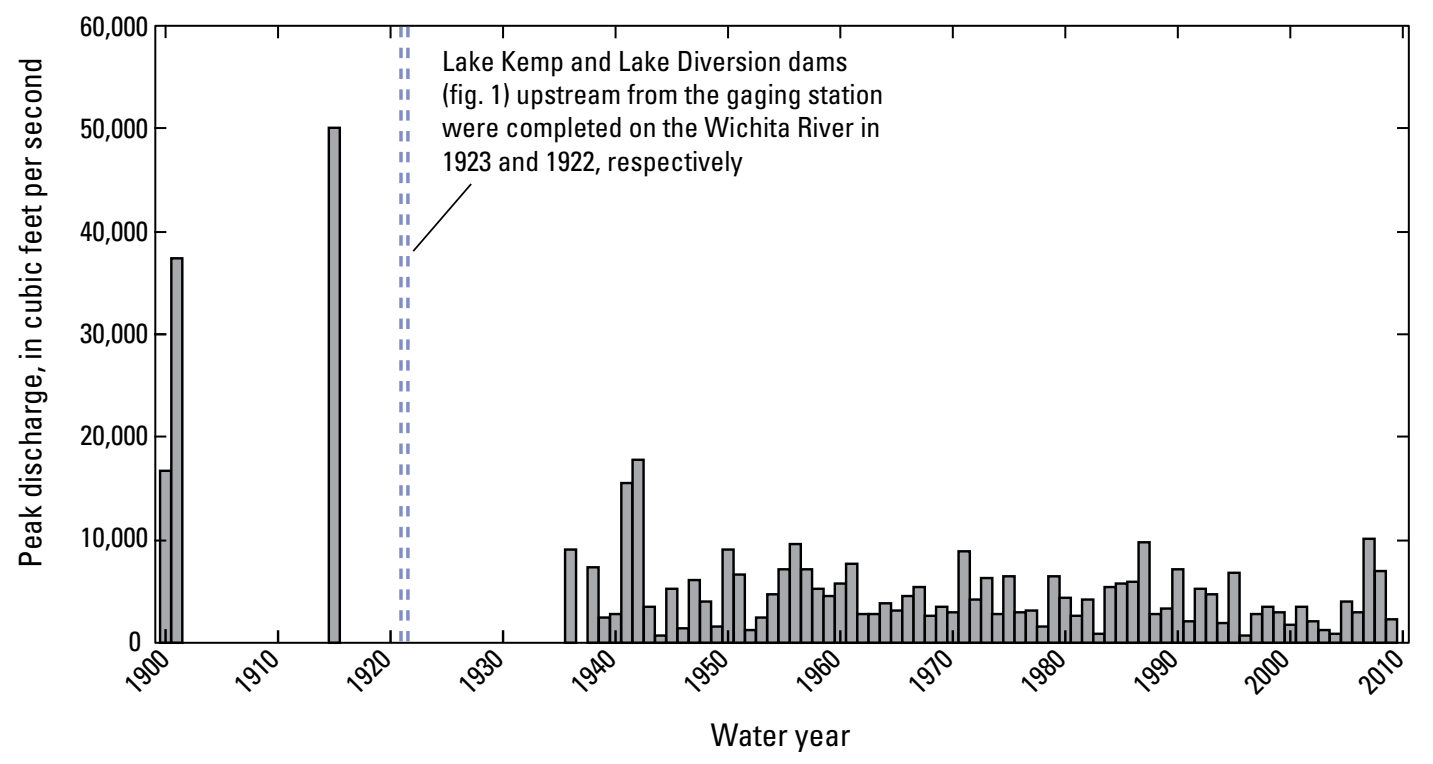

Figure 5. Annual peak discharges at U.S. Geological Survey streamflow-gaging station 07312500 Wichita River at Wichita Falls, Texas (Loop 11 gage). 
was cresting at Loop 11, Holliday Creek was about two-thirds bank full and flowing.

Aerial photographs were examined for evidence of development in the flood plain and for general changes in the density of riparian vegetation. Notable changes within the study reach between 1953 and 2008 include a general increase in vegetation density in the riparian area along the Wichita River channel. The aerial photographs indicate an increase in vegetation between 1953 and 1991 along the banks and in the flood plain at Lucy Park, 1 to 2 mi downstream from Loop 11. Photographs from 1968 and subsequent years (including 1971 and 1979, not shown here) indicate fill was placed on the south bank immediately downstream from Scott Avenue between 1971 and 1979. A long-term resident of the area indicated that a substantial amount of fill also was deposited on the north bank of the channel downstream from the Scott Avenue bridge in the early 1960s (Peter Pullin, oral commun., June 23, 2009). Aerial photographs as recent as 1968 show houses on the north bank of the Wichita River immediately downstream from Martin Luther King Junior Boulevard built on earth fill in the channel (fig. 6). The earth fill placed at the downstream side of Martin Luther King Junior bridge is currently (2011) a vacant field.

Houses were present on earth fill downstream from Martin Luther King Junior Boulevard when this photograph was taken.

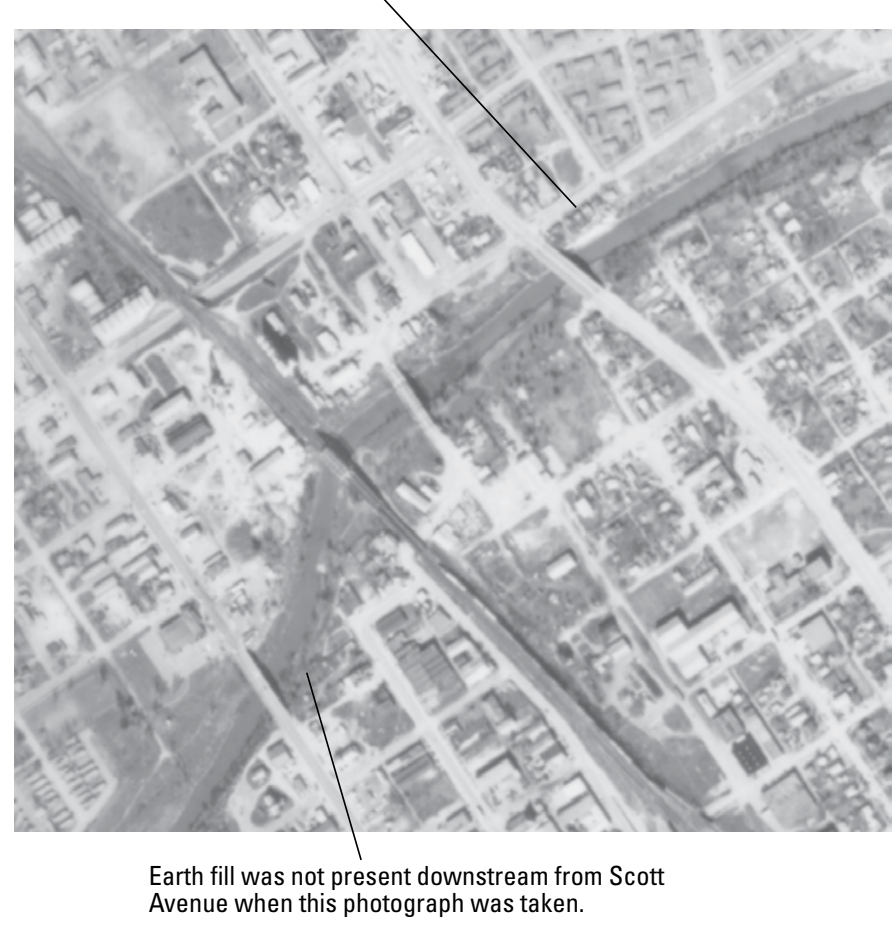

Figure 6. Scott Avenue and Martin Luther King Junior Boulevard bridges on the Wichita River, February 7, 1968 (photograph courtesy Tom Roehrig, Texas Natural Resources Information System).
Ground photographs taken near the Loop 11 gage were compiled for 1950, 1961, 1975, and 2009 (fig. 7). The photographs indicate a substantial amount of riparian vegetation growth occurred between 1950 and 2009. When reservoirs are constructed, riparian growth in downstream reaches often increases (Collier and others, 1996; Shafroth and others, 2002; Heitmuller and Greene, 2009). An August 23,2010 , aerial photograph indicated a dense corridor of riparian growth along the segment of the river immediately downstream from Loop 11 (fig. 8).

Cross sections were used to assess the stability of the Wichita River channel in the study area. A plot of Loop 11 cross sections over time (fig. 9) indicates that, while minor changes in cross-section shape are observed, the thalweg (elevation of the flowline joining the lowest points along the streambed, thus defining the deepest channel of the stream) and the width of the channel are fairly stable. Most of the Wichita River cross sections surveyed in 2009 by the USGS compared favorably with those from the 1986 photogrammetric survey, indicating that much of the Wichita River channel in the study area appears to be fairly stable. However, four consecutive cross sections between 0.9 and 2.6 mi downstream from Martin Luther King Junior Boulevard indicated substantial narrowing (fig. 10). For those four cross sections, the loss in channel width was typically 30 to $50 \mathrm{ft}$.

For most bridges, comparison of the 2009 surveys of the channels and bridge openings to the as-built bridge plans indicates no change in cross section. Obstructions caused by earth fill are evident in cross sections on the right bank at the downstream side of the Scott Avenue bridge (south span) and on the left bank at the Martin Luther King Junior bridge (north span). Obstructions in the cross section near the Scott Avenue bridge (fig. 11A; fig. 12) reduce the effective conveyance of the bridge section during floods. The obstruction at the Martin Luther King Junior bridge only partially blocks flow, reducing channel conveyance during floods (fig. 11B; fig. 13).

Values of Manning's $n$ selected by USGS personnel during the 2009 survey of Wichita River cross sections in the 5-mi reach of the Wichita River downstream from the Loop 11 gage were compared to values used in the 1991 FEMA HEC-2 model. Roughness values selected for the channel were nearly identical to values from the 1991 FEMA HEC-2 model. However, roughness values selected for the overbank were about 2.5 times larger than those used in the 1991 FEMA HEC-2 model. 
1950

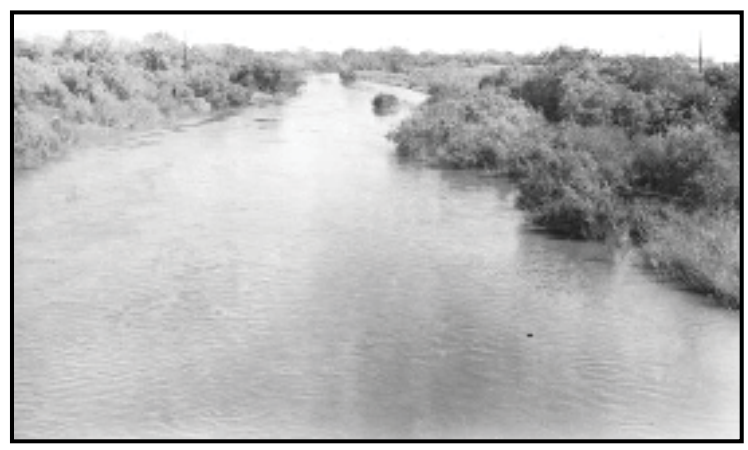

1961

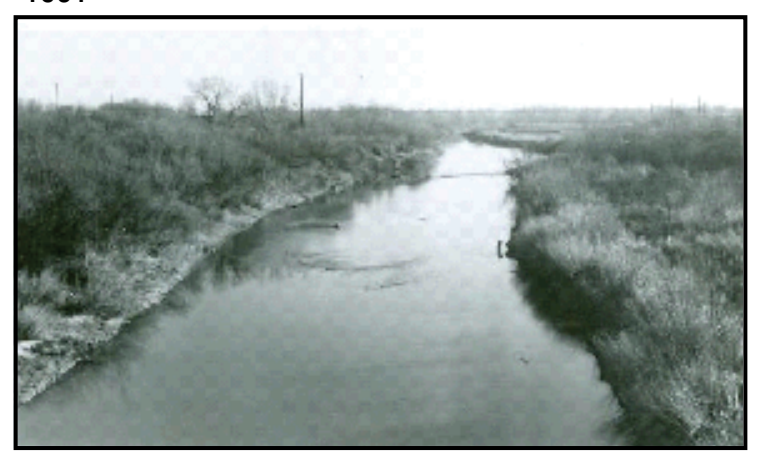

1975

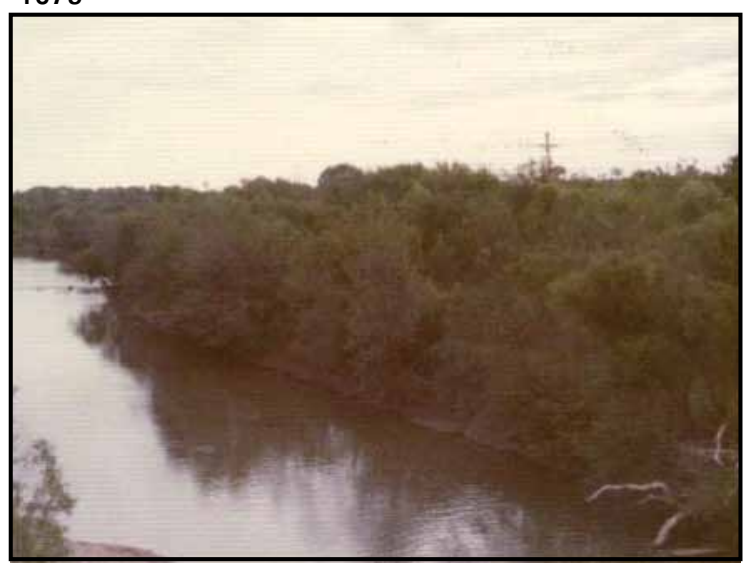

2009

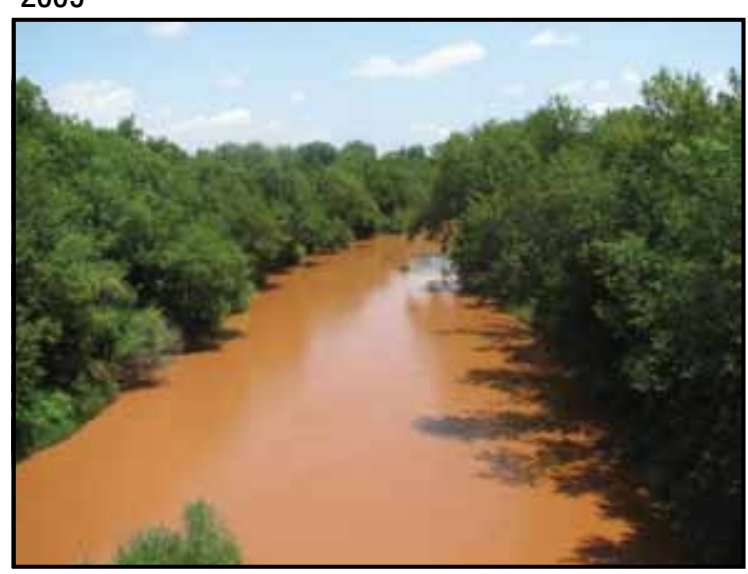

"Floods are a key element in the future management of dams. Without periodic high flows, some channels downstream from dams will aggrade with sediment or narrow with overgrown vegetation. Two or three flood-free decades may have been traded for more devastating floods in the future."

- from Dams and Rivers: $A$ Primer on the Downstream Effects of Dams (Collier and others, 1996)

\section{U.S. Geological Survey}

Circular 1126

Figure 7. Wichita River looking downstream from Loop 11 in 1950, 1961, 1975, and 2009 at U.S. Geological Survey streamflow-gaging station 07312500 Wichita River at Wichita Falls, Texas. 


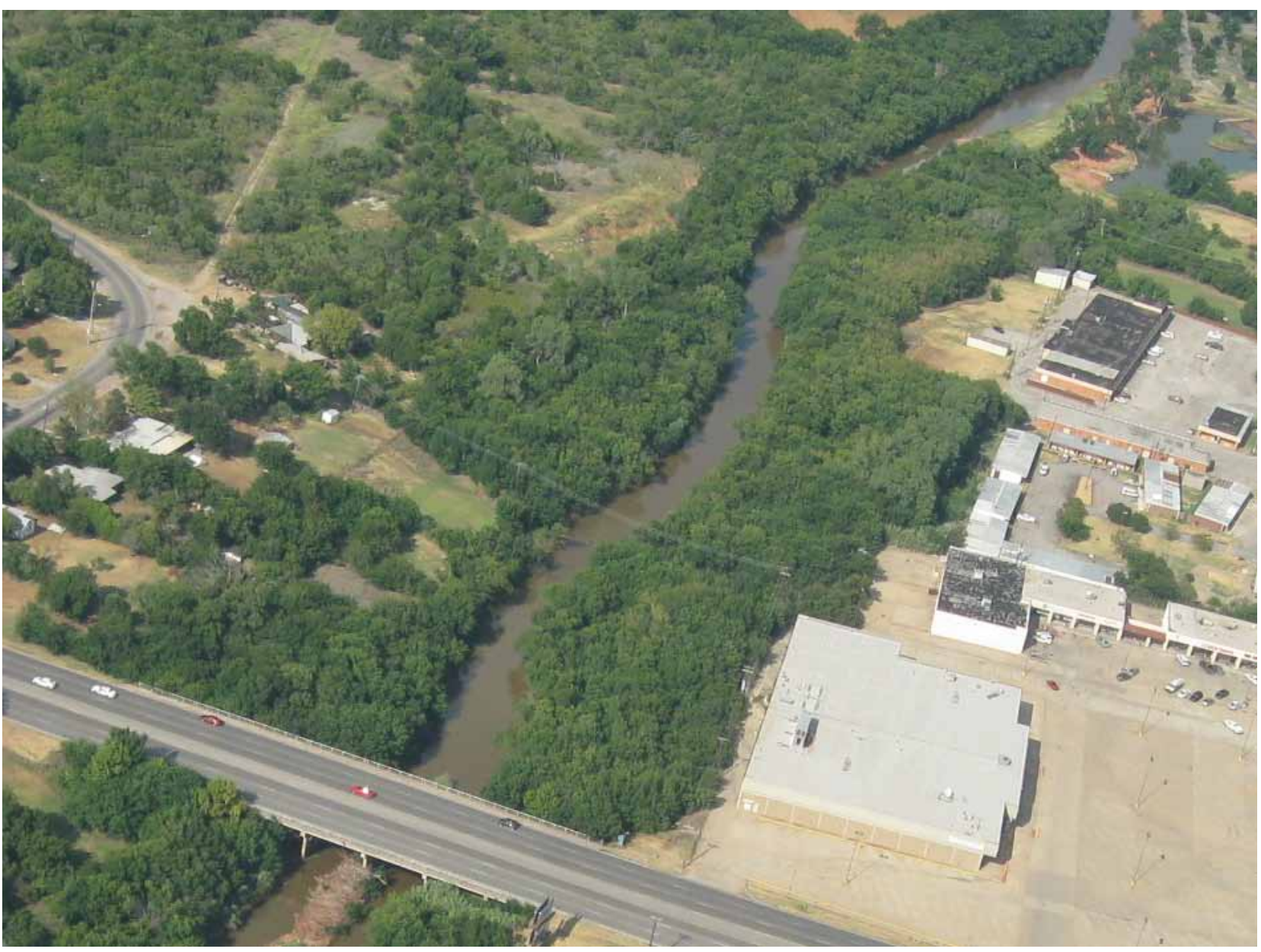

Figure 8. Wichita River looking downstream from Loop 11, August 23, 2010, Wichita Falls, Texas.

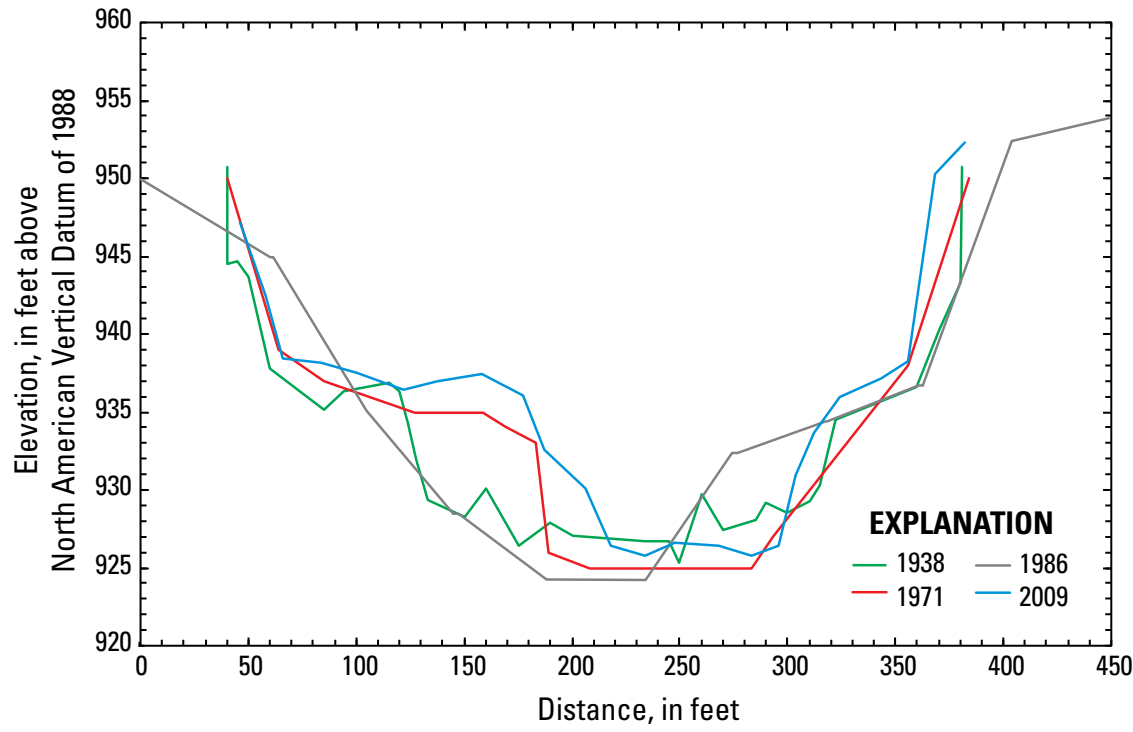

Figure 9. Historical channel cross sections of the Wichita River at U.S. Geological Survey streamflow-gaging station 07312500 Wichita River at Wichita Falls, Texas, 1938-2009. 

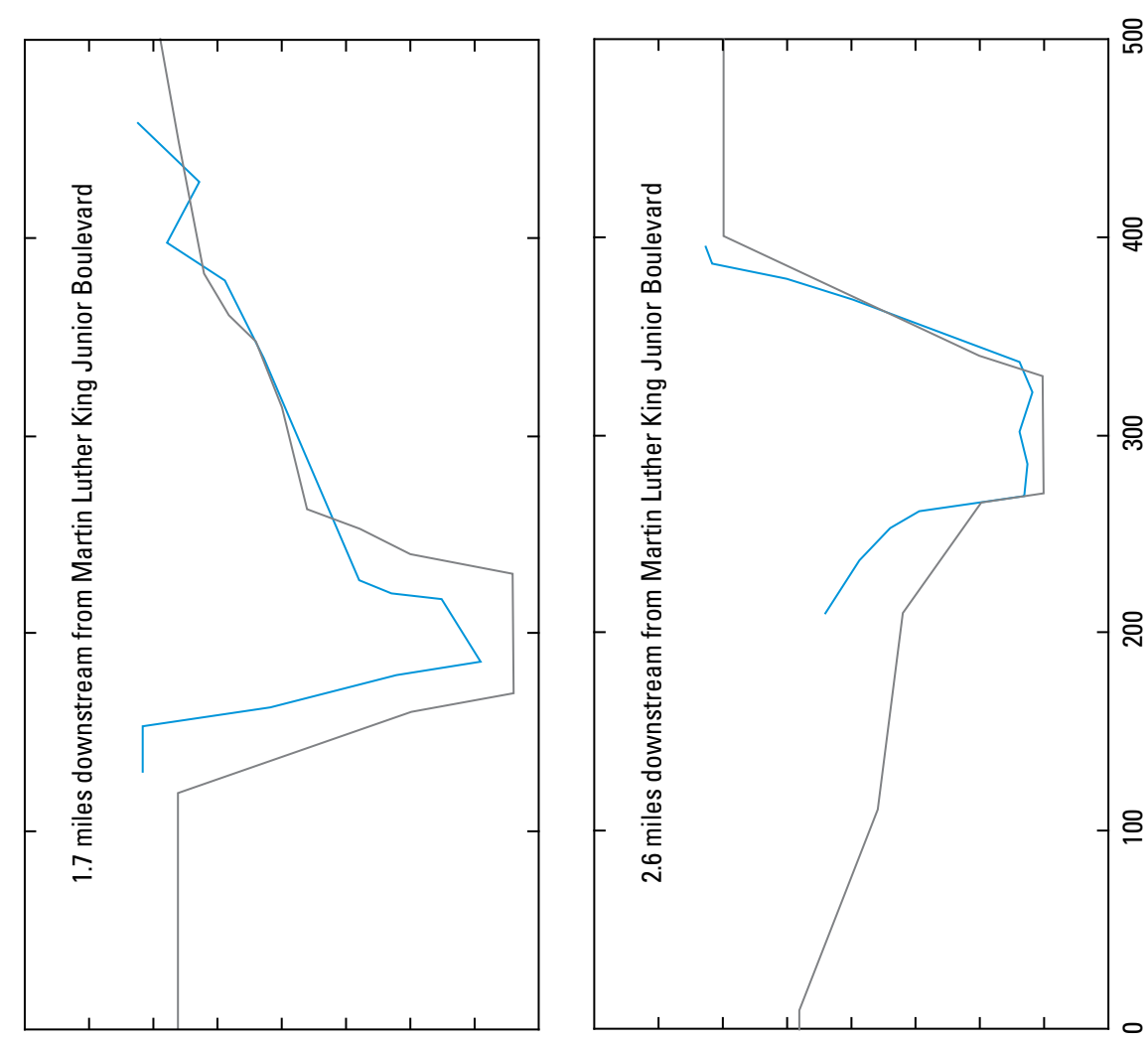

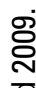

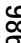

菑

is

尝

:

cis

$\stackrel{3}{\frac{1}{2}}$

高

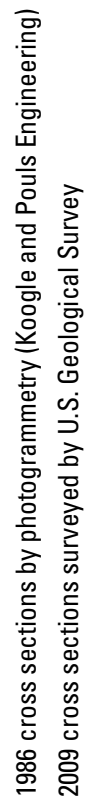

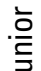

西
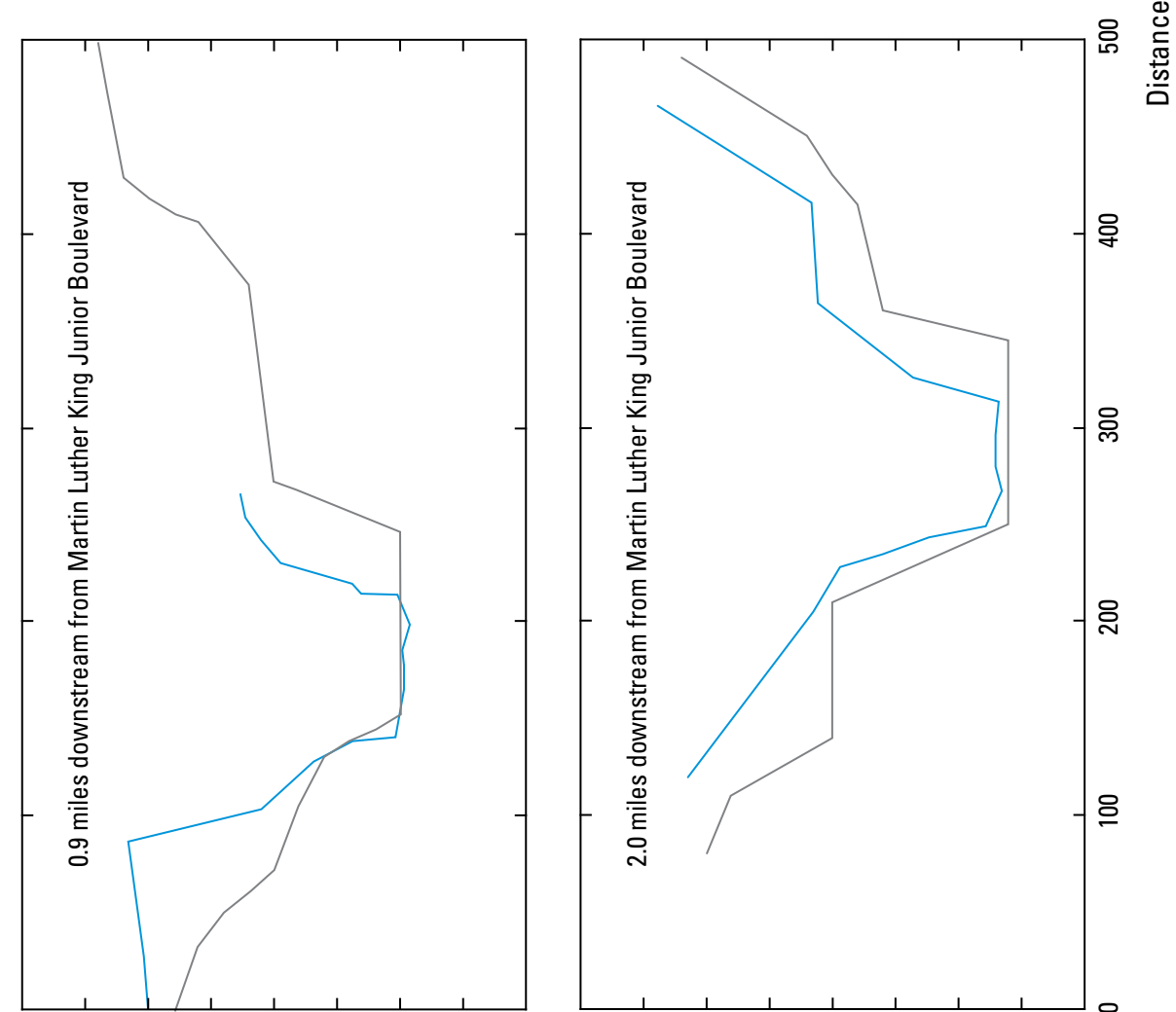

롱

ब.

品

$\sum_{2}^{\infty}$ 

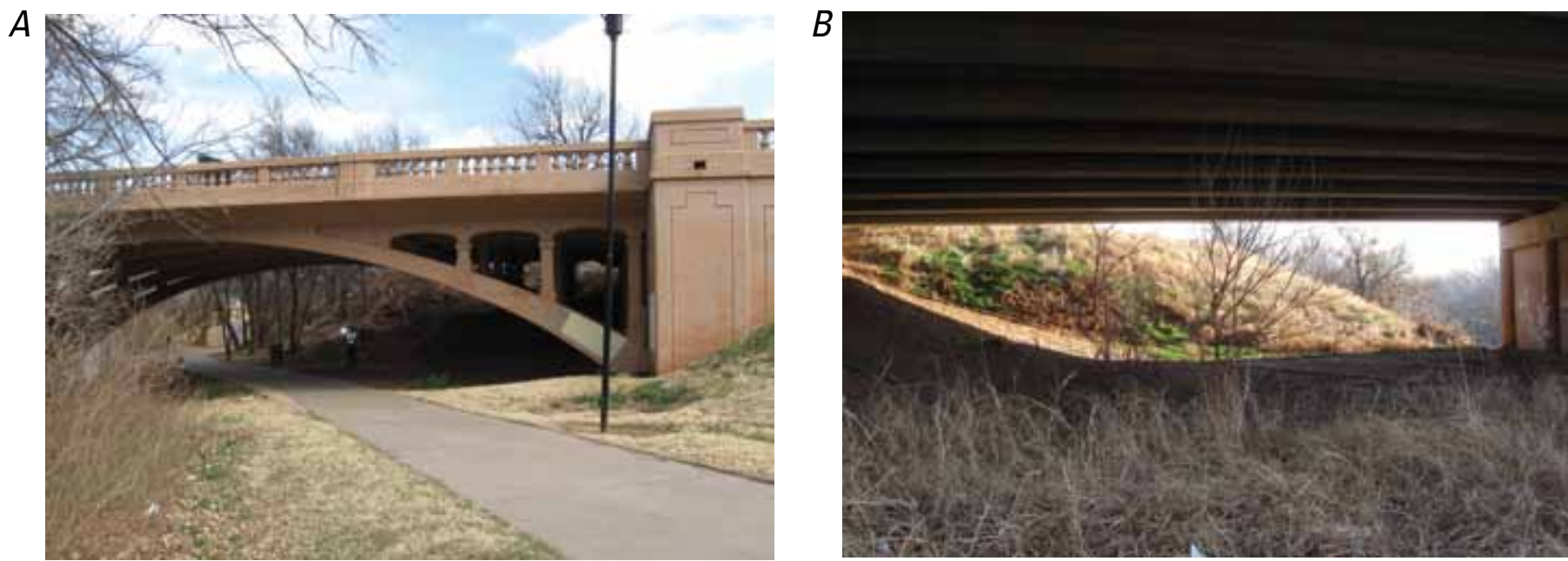

Figure 11. Wichita River obstructions $A$, on the right (south) bank at the downstream side of Scott Avenue bridge looking downstream and $B$, on the left bank at Martin Luther King Junior Boulevard bridge, looking downstream, February 23, 2009.

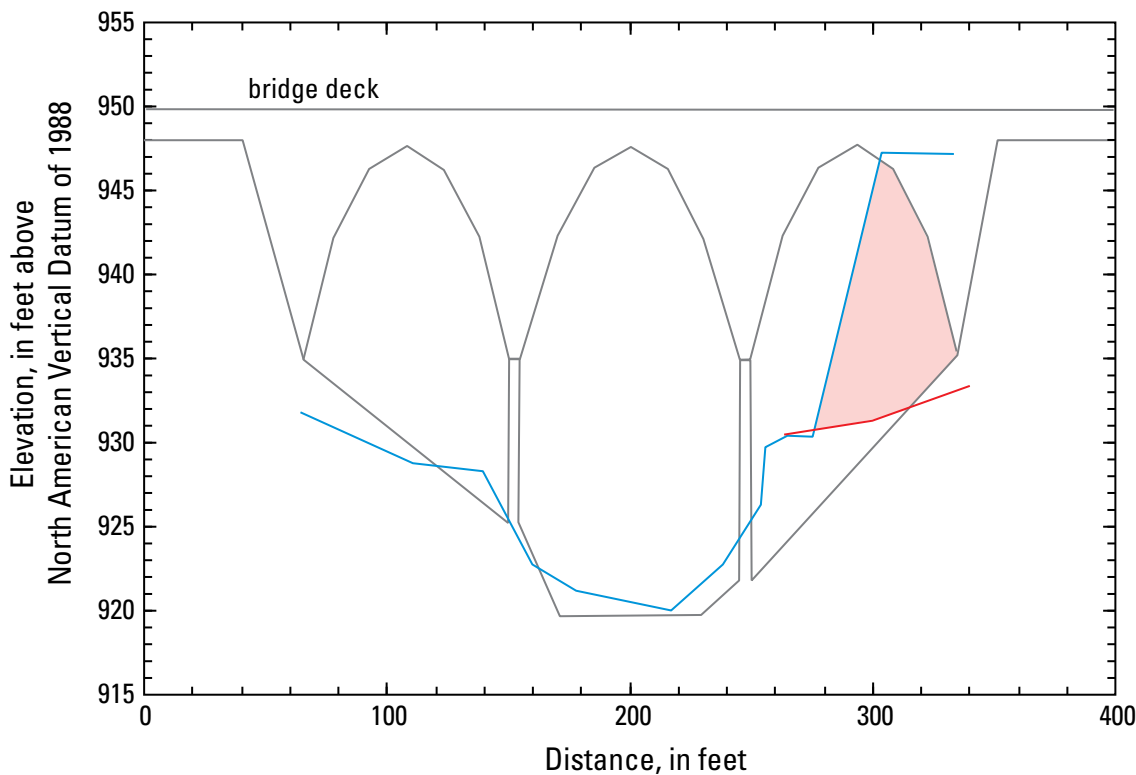

\section{EXPLANATION}

- 1986 (at upstream face of bridge)

2009 (underneath bridge)

2009 (immediately downstream from bridge)

Blocked opening

Figure 12. Wichita River cross sections from 1986 and 2009, and the obstruction on the right (south) bank at the downstream side of Scott Avenue bridge in Wichita Falls, Texas.

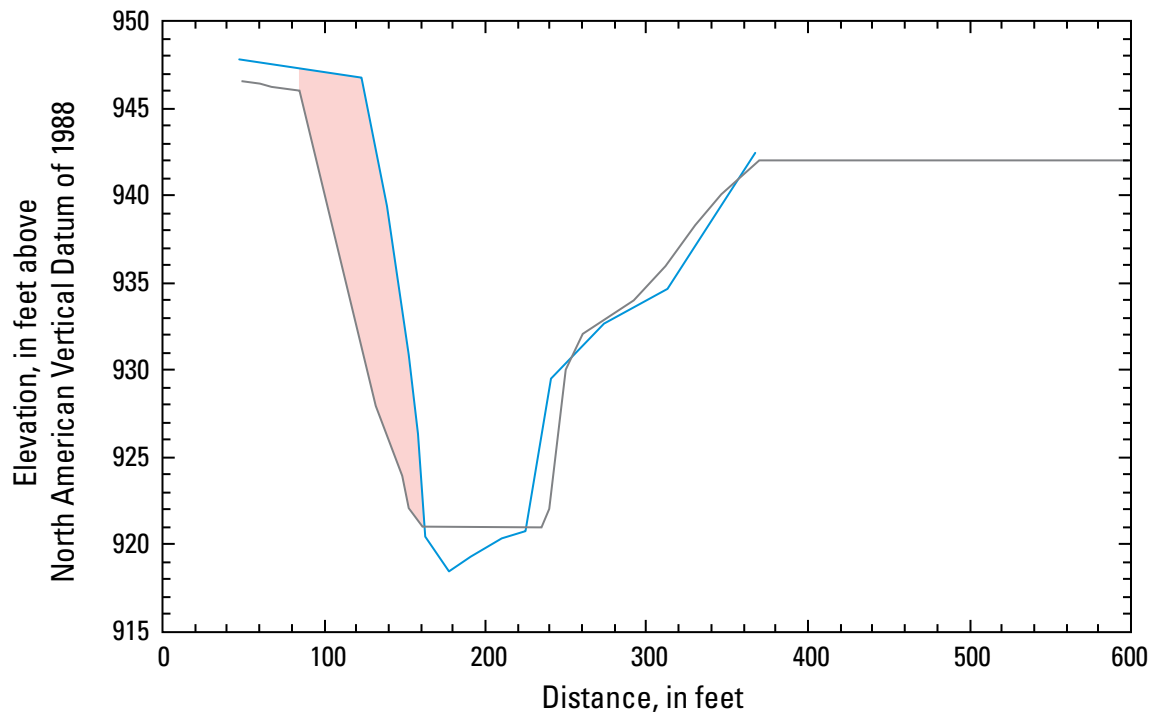

Figure 13. Wichita River cross sections from 1986 and 2009 and the obstruction on the left (north) bank at the downstream side of the Martin Luther King Junior Boulevard bridge in Wichita Falls, Texas.

- 1986 (at upstream face of bridge)

2009 (immediately downstream from bridge) Blocked opening 


\section{Models of Historical Floods and Effects of Backwater on Flood Stage}

The floods of 2007, 2008, and 1941 on the Wichita River were modeled by using the one-dimensional, steadystate, step-backwater model described in the Step-Backwater Modeling section to prepare the calibrated model for evaluating different flood-mitigation alternatives. The 2007 flood is of greatest interest because it crested at a higher stage than any other flood since at least 1938. The 2008 flood was also used to calibrate the step-backwater model. Because channel conditions during 1941 were different compared to channel conditions during 2007 and 2008, modeling of the 1941 flood is useful in the analysis of potential mitigation alternatives. Calibration of the 2007 and 2008 floods was done by adjusting Manning's $n$ so that differences in computed and observed water-surface elevations at the Loop 11 gage and the staff gages were minimized. Interaction of Wichita River and Holliday Creek flows and water-surface elevations was also modeled to assess the effects of backwater on flood stage.

\section{Flood}

Calibration of the model to the June 2007 flood indicated Manning's $n$ was as large as 0.22 in the roughest areas of the flood plain (the densely vegetated banks and overbanks composing the flood plain) and 0.048 in the Wichita River channel (for comparison, in the 1991 FEMA HEC-2 model, average Manning's $n$ for the flood plain and channel were 0.07 and 0.04 , respectively.) The relatively large calibrated roughness values for the June 2007 flood are indicative of a densely vegetated flood plain and a rougher-thanaverage natural channel (Chow, 1959). These relatively large roughness values also correspond with relatively low streamflow velocities (fig. 4). The calibrated water-surface profile elevations (fig. 14) for the 2007 flood are within $0.02 \mathrm{ft}$ of the recorded peak stage at the Loop 11 gage and within $0.06 \mathrm{ft}$ of the observed peak stage at the Tanglewood subdivision. The calibrated water-surface profile elevations were 0.45 and $0.42 \mathrm{ft}$ lower, respectively, than the observed peak stages at the city staff gages near Interstate 44 and downstream from Martin Luther King Junior Boulevard (fig. 14). The greater differences in water-surface profile elevations at these two locations might be because of the magnitude or timing of the flood peak on Holliday Creek.

\section{Flood}

The August 2008 flood peaked about $4 \mathrm{ft}$ lower than the 2007 flood. Calibration of the August 2008 flood indicated flood-plain roughness as large as 0.22 in the roughest areas

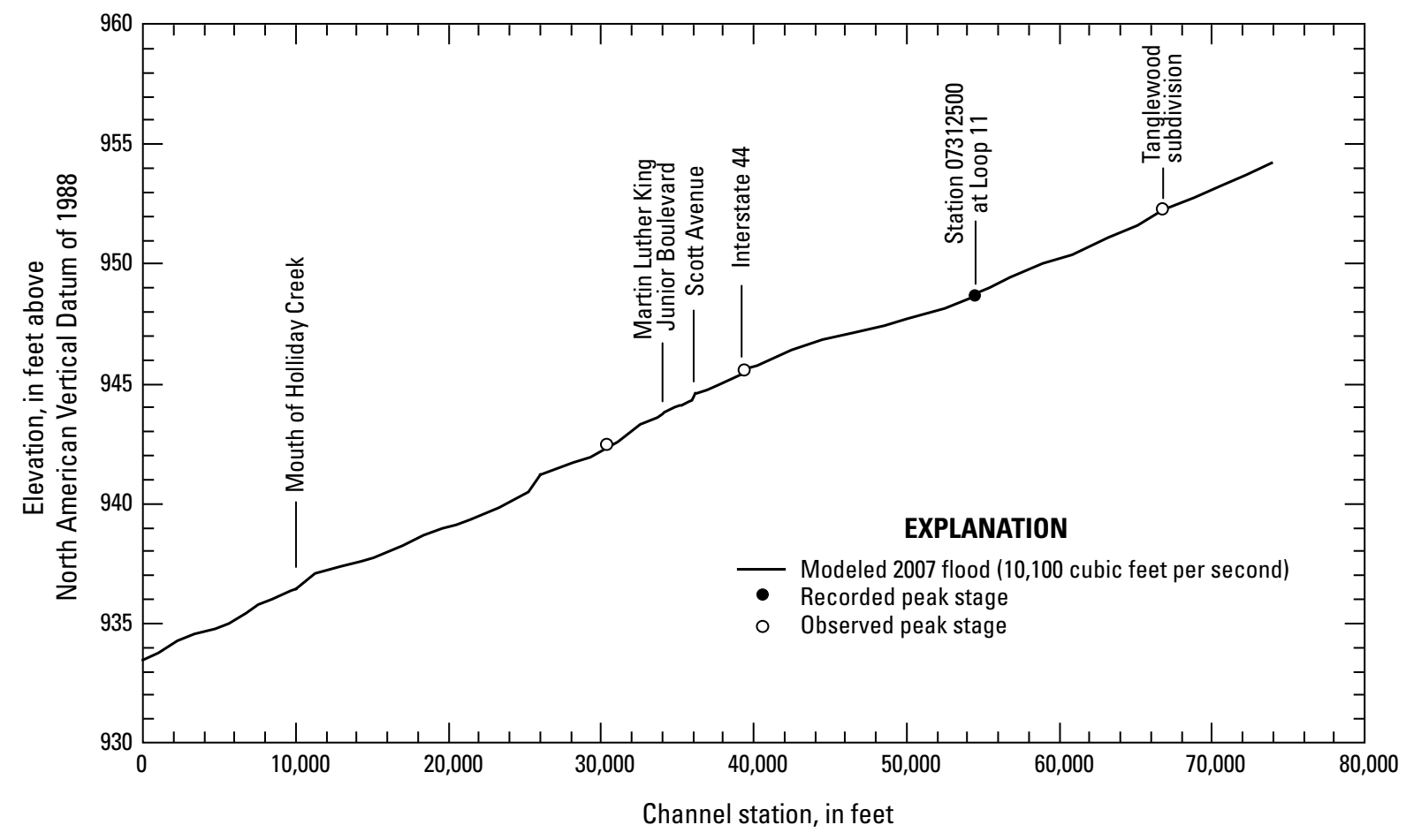

Figure 14. Calibrated water-surface profile for the 2007 flood on the Wichita River at Wichita Falls, Texas. 
of the flood plain, but the Wichita River channel roughness was 0.041 ; this is a fairly typical value for a natural channel (Chow, 1959). The difference between the 2007 and 2008 calibrated Manning's $n$ for the Wichita River channel could be because of the 4-ft stage difference between the two floods and the increased effect of overhanging branches at higher stages (as shown in the 2009 photograph in fig. 7). The calibrated water-surface profile elevations (fig. 15) for the 2008 flood are within $0.02 \mathrm{ft}$ of the recorded peak stage at the Loop 11 gage and the observed peak stage at the city staff gage downstream from Martin Luther King Junior Boulevard. The calibrated water-surface profile elevation was $0.30 \mathrm{ft}$ higher than the observed peak stage near Interstate 44 and $1.06 \mathrm{ft}$ lower than the observed peak stage at the Tanglewood subdivision (fig. 15). Channel roughness might vary longitudinally upstream from the Loop 11 gage. During the calibration, no attempt was made to assess the longitudinal variability of the channel roughness.

Cross-section conveyance at Loop 11 from the 1991 FEMA model (with 1991 roughness coefficients) and crosssection conveyance from 2009 (with roughness coefficients selected in 2009 by the USGS) were compared (fig. 16). The stage (elevation) associated with a given conveyance is consistently lower in the 1991 FEMA model compared to the 2009 flood, and the divergence between the two curves increases markedly at higher stages. While this might be in part because of the manner in which the 1991 roughness coefficients were selected, it likely indicates that additional cross-section conveyance has been lost between 1991 and 2009 because of the growth of riparian vegetation.

\section{Flood}

The October 3, 1941, flood peaked at $24.00 \mathrm{ft}$ at the Loop 11 gage with a discharge of $17,800 \mathrm{ft}^{3} / \mathrm{s}$. The much larger 1941 flood discharge flowed at a slightly lower stage compared to the $2007 \mathrm{flood}$ of $10,100 \mathrm{ft}^{3} / \mathrm{s}$. A "clean" channel free of vegetation conveys water more efficiently and has a smaller Manning's $n$ value compared to a channel with vegetation growing on the banks and overbanks. The 1941 flood is useful for answering the question of how "clean"

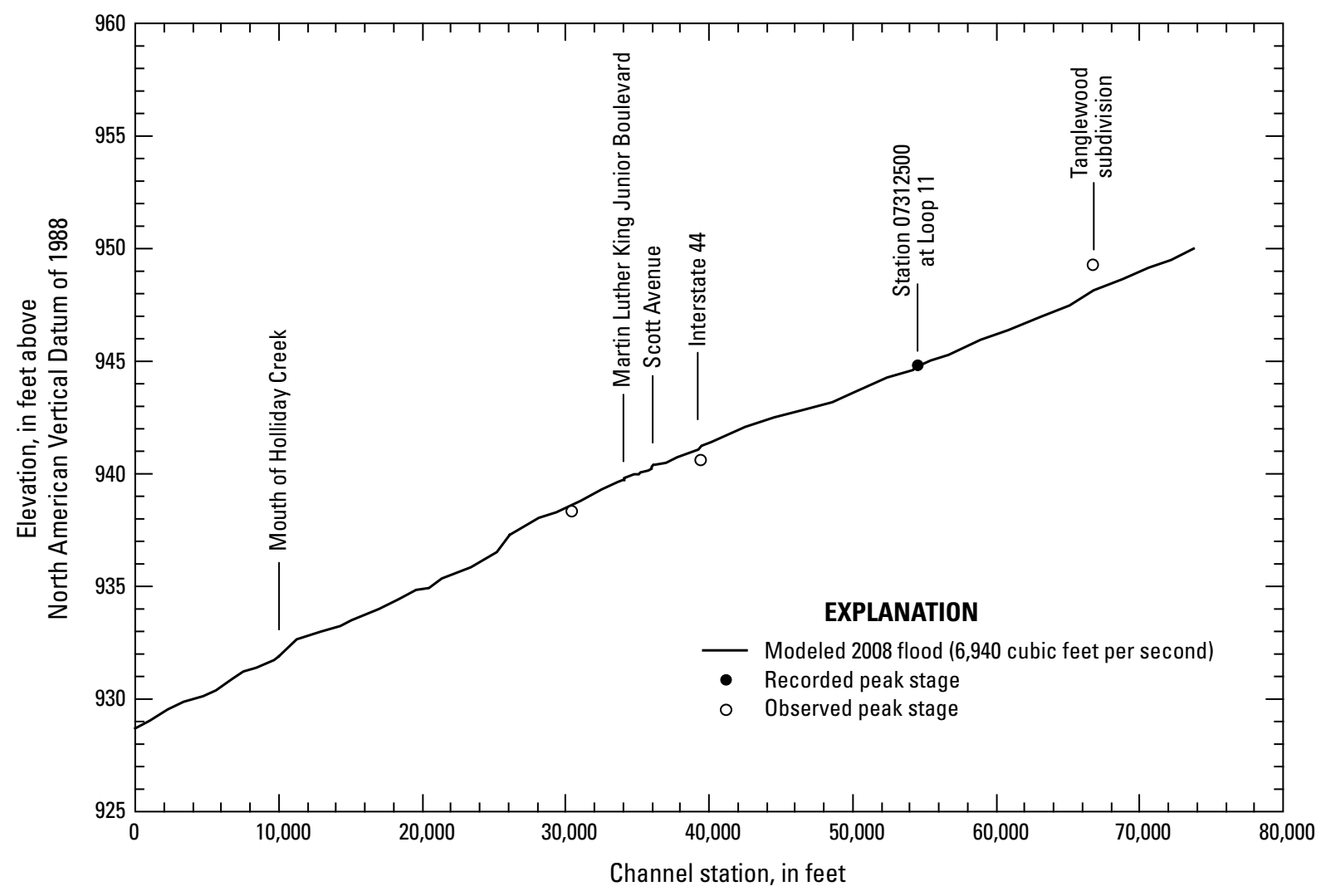

Figure 15. Calibrated water-surface profile for the 2008 flood on the Wichita River at Wichita Falls, Texas. 


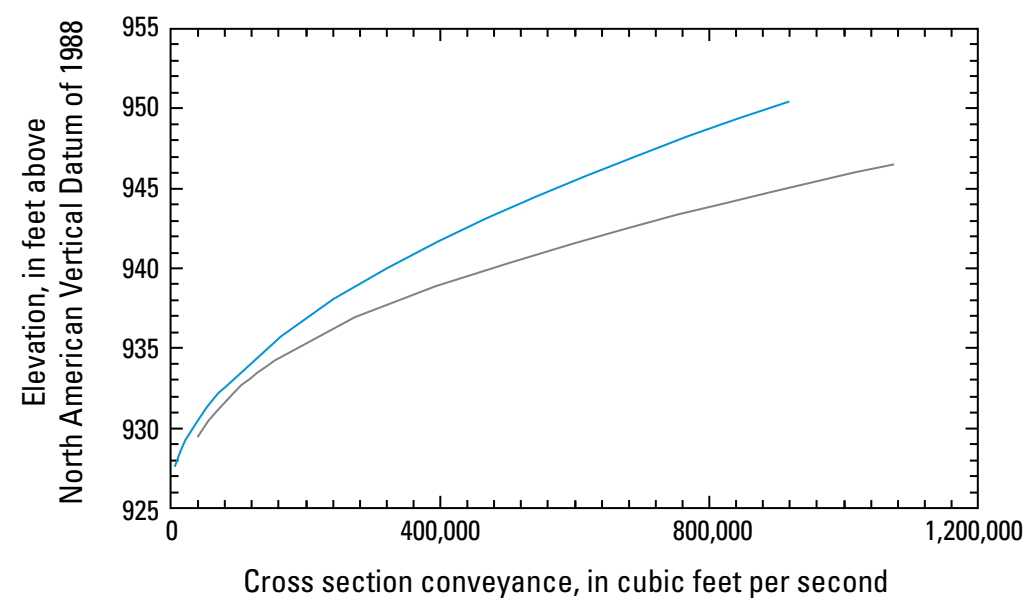

Figure 16. Cross-section conveyance computed from 1991 Federal Emergency Management (FEMA) HEC-2 model (1991 FEMA) and 2009 U.S. Geological Survey HEC-RAS model (2009 USGS) at U.S. Geological Survey streamflow-gaging station 07312500 Wichita River at Wichita Falls, Texas (Loop 11 gage).

was the channel historically. The first steps in modeling the 1941 flood include the simulated removal of all bridge obstructions near Scott Avenue and Martin Luther King Junior Boulevard (figs. 11-13), and of the aggraded channel banks downstream from Martin Luther King Junior Boulevard (fig. 10). The extent of the earth-fill areas in cross sections near the Scott Avenue and Martin Luther King Junior bridges was determined from patterns in the 2 -ft elevation contours, and these fill areas - as evidenced from aerial photographs, historical cross sections, and discussions with the owner of a business on Scott Avenue adjacent to the Wichita River (Peter Pullin, oral commun., June 23, 2009) — were most likely placed after the 1941 flood. These fill areas near the Scott Avenue and Martin Luther King Junior bridges were removed from the cross sections used to model the 1941 flood. The 1941 flood was calibrated solely on the basis of its recorded peak stage at the Loop 11 gage. The calibrated Manning's $n$ for the Wichita River channel for the 1941 flood is 0.030 , which is a relatively small value for a natural channel, indicating that the channel was cleaner in 1941 compared to 2007 when the Manning's $n$ for the Wichita River was 0.048 . The calibrated water-surface profile for the 1941 flood is shown in figure 17, along with the calibrated 2007 flood profile for comparison.

\section{Effects of Backwater on Wichita River and Holliday Creek}

Stages on Wichita River at the Loop 11 gage and Holliday Creek gage are at times affected by backwater-a large inflow from Holliday Creek can cause backwater at the Loop 11 gage, and large flows in the Wichita River can cause backwater at the Holliday Creek gage. During low-flow conditions, the streams often act independently of each other and there is no relation between their stages. However, moderate rises on either stream can cause backwater, affecting the stage on the other stream. Because of the difference in drainage area of the two streams, flood peaks on Holliday Creek typically occur several hours earlier than peaks on the Wichita River. However, depending on the timing of the rainfall in the two basins, the Wichita River and Holliday Creek can rise concurrently. Eight storm hydrographs on Wichita River and Holliday Creek during the 2010 water year were analyzed to determine the timing of peaks on the two streams and to assess the degree to which each was affected by backwater. Understanding backwater effects during runoff events in 2010 provides insight into how flow-induced backwater might have contributed to higher stages during the 2007 flood.

Stage hydrographs for the Loop 11, Holliday Creek, and Wichita River near Charlie, Tex., gages were plotted for each storm hydrograph inspected for indications of backwater effects. The stage hydrographs for two of the eight storms, one during January 27-February 3, 2010, and another during July $8-13,2010$, are depicted (fig. 18). For the eight storms, four of the Holliday Creek runoff peaks produced minor backwater in the Wichita River at the Loop 11 gage. Three of the eight storms resulted in a backwater rise at the Holliday Creek gage followed by a peak unaffected by backwater. Despite the difference in drainage-area sizes of the Wichita River and Holliday Creek basins, runoff from the Holliday Creek basin during concurrent runoff events often contributes to peak stages at the Wichita River near Charlie gage (table 4).

The timing of peak flow on each stream affects backwater, and the lag time between flow at the Holliday Creek gage and the Loop 11 gage is variable. On the basis of the storm hydrographs from the 2010 water year, the Wichita 


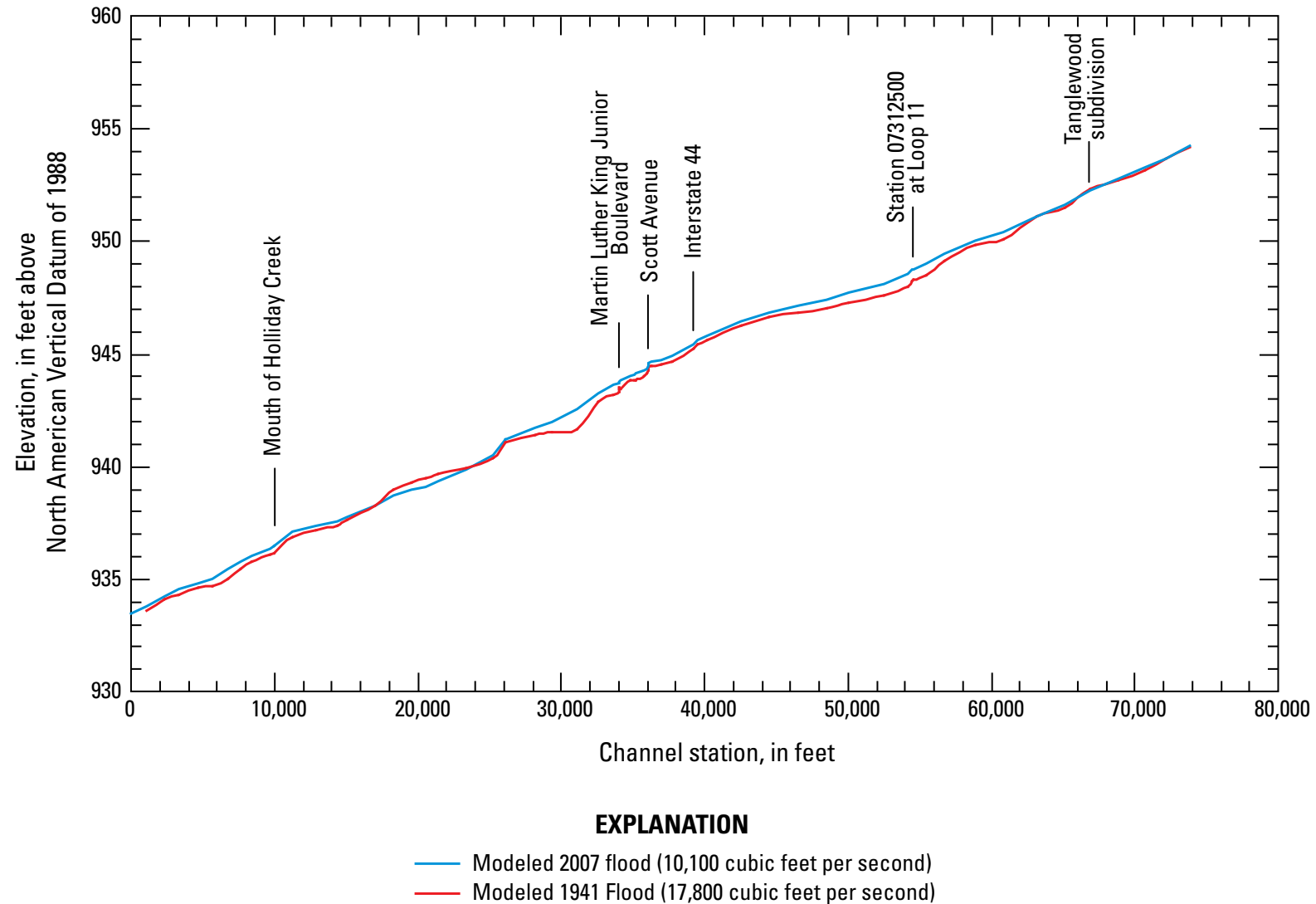

Figure 17. Calibrated water-surface profiles for the 2007 and 1941 floods on the Wichita River at Wichita Falls, Texas.
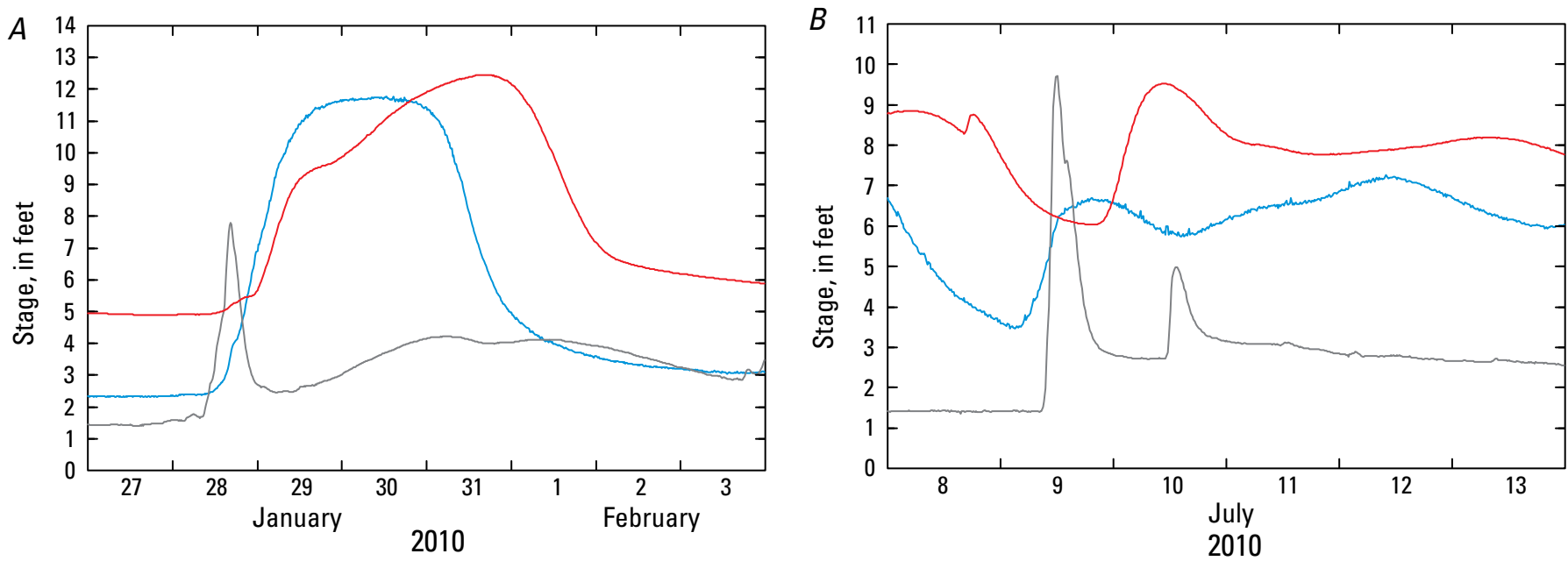

EXPLANATION

- 07312500 Wichita River at Wichita Falls, Tex. (Datum of gage is 924.53 feet above North American Vertical Datum of 1988 [NAVD 88])

— 07312610 Holliday Creek at Wichita Falls, Tex. (Datum of gage is 919.61 feet above NAVD 88)

— 07312700 Wichita River near Charlie, Tex.

(Datum of gage is 872.99 feet above NAVD 88)

Figure 18. Stage hydrographs during A, January 2010, and $B$, July 2010 at U.S. Geological Survey streamflow-gaging stations 07312500 Wichita River at Wichita Falls, Texas (Loop 11 gage), 07312610 Holliday Creek at Wichita Falls, Tex. (Holliday Creek gage), and 07312700 Wichita River near Charlie, Tex. (Wichita River near Charlie, Tex., gage). 
River at Loop 11 typically peaks about 34 hours after Holliday Creek. However, the lag varied from as little as about 7 hours to as much as 44 hours (table 4). Although the January 2010 storm peaked at the Loop 11 gage 44 hours after the Holliday Creek gage, the Wichita River was nearing its peak within about 24 hours of the peak at the Holliday Creek gage (fig. 18A). During the July 2010 storm, the Wichita River at Loop 11 peaked only about 7 hours after Holliday Creek (fig. 18B). Holliday Creek was observed by USGS personnel to be flowing at the peak of the 2007 flood recorded at the Loop 11 gage, and the peaks from Wichita River and Holliday might have occurred at approximately the same time during the 2007 flood. When the rivers rise concurrently, the stage of the peak on Wichita River can increase because of backwater effects. The January 2010 hydrographs (fig. 18A) might represent the typical stream responses at all three gages: a sharp rise and recession on Holliday Creek, a broad rise on the Wichita River at the Loop 11 gage, and a lagged and dampened pattern at the Wichita River near Charlie, Tex., gage compared to the hydrographs of the upstream gages.

Water-surface profiles were computed for Holliday Creek without backwater from Wichita River using the HEC-RAS model and cross sections obtained from the 2-ft elevation contours provided by the City of Wichita Falls. Channel roughness was calibrated on the basis of the April 19, 2010, measured discharge of 1,220 $\mathrm{ft}^{3} / \mathrm{s}$ at a stage of $8.90 \mathrm{ft}$ (928.51 ft above NAVD 88) at the Holliday Creek gage. The calibrated Manning's $n$ for Holliday Creek is
0.031, a reasonable value for a relatively straight, grass-lined channel (Chow, 1959). The water-surface profiles (fig. 19) were initiated at the mouth of Holliday Creek using slopeconveyance computations.

The 2010 step-backwater model was used to assess the potential extent of backwater during flooding at the confluence of Wichita River and Holliday Creek. Large floods on the Wichita River result in backwater conditions on Holliday Creek. Backwater conditions in Holliday Creek caused by a discharge of 10,100 $\mathrm{ft}^{3} / \mathrm{s}$ (the 2007 flood) in the Wichita River channel were modeled. Flows in Holliday Creek ranging from 200 to $6,000 \mathrm{ft}^{3} / \mathrm{s}$ were modeled assuming a flow of $10,100 \mathrm{ft}^{3} / \mathrm{s}$ in Wichita River. Figure 20 depicts computed water-surface profiles for Holliday Creek with backwater caused by a streamflow of $10,100 \mathrm{ft}^{3} / \mathrm{s}$ (the peak discharge of the 2007 flood) in the Wichita River.

Figure 21 depicts the effects of backwater from Holliday Creek on computed water-surface profiles on the Wichita River at Wichita Falls, Tex., for a flood in the Wichita River of $10,100 \mathrm{ft}^{3} / \mathrm{s}$ (the peak of the $2007 \mathrm{flood}$ ). Water-surface profiles were computed starting 1.9 mi downstream from the confluence of the Wichita River and Holliday Creek upstream to where the Fort Worth-Denver Railroad crosses the Wichita River, upstream from the Tanglewood subdivision. The effects of flows ranging from 0 to $6,000 \mathrm{ft}^{3} / \mathrm{s}$ in Holliday Creek on water-surface elevation were modeled for the Wichita River. Water-surface elevations downstream from the confluence of the two streams represent the combined flows of Wichita

Table 4. Peak stages at U.S. Geological Survey streamflow-gaging stations on Wichita River and Holliday Creek, north Texas, October 2009-September 2010.

\begin{tabular}{ccccccccc}
\hline \multicolumn{2}{c}{$\begin{array}{c}\text { 07312500 Wichita River } \\
\text { at Wichita Falls, Tex. } \\
\text { (Loop 11 gage) }\end{array}$} & \multicolumn{2}{c}{$\begin{array}{c}\text { 07312610 Holliday Creek } \\
\text { at Wichita Falls, Tex. } \\
\text { (Holliday Creek gage) }\end{array}$} & \multicolumn{2}{c}{$\begin{array}{c}\text { 07312700 Wichita River } \\
\text { near Charlie, Tex. } \\
\text { (Wichita River near Charlie gage) }\end{array}$} \\
\hline Date & Time & $\begin{array}{c}\text { Peak stage, } \\
\text { (feet) }\end{array}$ & Date & Time & $\begin{array}{c}\text { Peak stage, } \\
\text { (feet) }\end{array}$ & Date & Time & $\begin{array}{c}\text { Peak stage, } \\
\text { (feet) }^{3}\end{array}$ \\
\hline $10 / 10 / 2009$ & 1630 & 5.15 & $10 / 08 / 2009$ & 2345 & 8.82 & $10 / 09 / 2009$ & 2145 & 7.42 \\
$1 / 30 / 2010$ & 1230 & 11.78 & $1 / 28 / 2010$ & 1630 & 7.78 & $1 / 31 / 2010$ & 1615 & 12.44 \\
$4 / 18 / 2010$ & 2130 & 12.44 & $4 / 17 / 2010$ & 2200 & 10.07 & $4 / 19 / 2010$ & 0330 & 15.87 \\
$5 / 15 / 2010$ & 0815 & 11.77 & $5 / 14 / 2010$ & 0815 & 12.09 & $5 / 15 / 2010$ & 1700 & 16.36 \\
$6 / 16 / 2010$ & 1830 & 4.03 & $6 / 14 / 2010$ & 2330 & 7.64 & $6 / 15 / 2010$ & 1915 & 7.27 \\
$7 / 09 / 2010$ & 1915 & 6.69 & $7 / 09 / 2010$ & 1200 & 9.72 & $7 / 10 / 2010$ & 1030 & 9.53 \\
$9 / 03 / 2010$ & 0015 & 3.52 & $9 / 02 / 2010$ & 0030 & 9.43 & $9 / 02 / 2010$ & 1930 & $6.69^{4}$ \\
$9 / 09 / 2010$ & 1430 & 6.32 & $9 / 08 / 2010$ & 0800 & 8.98 & $9 / 09 / 2010$ & 0500 & 8.31 \\
\hline
\end{tabular}

${ }^{1}$ Datum of gage is 924.53 feet above North American Vertical Datum of 1988.

${ }^{2}$ Datum of gage is 919.61 feet above North American Vertical Datum of 1988.

${ }^{3}$ Datum of gage is 872.98 feet above North American Vertical Datum of 1988.

${ }^{4}$ No stage data for 9/04/2010 through 9/06/2010. 


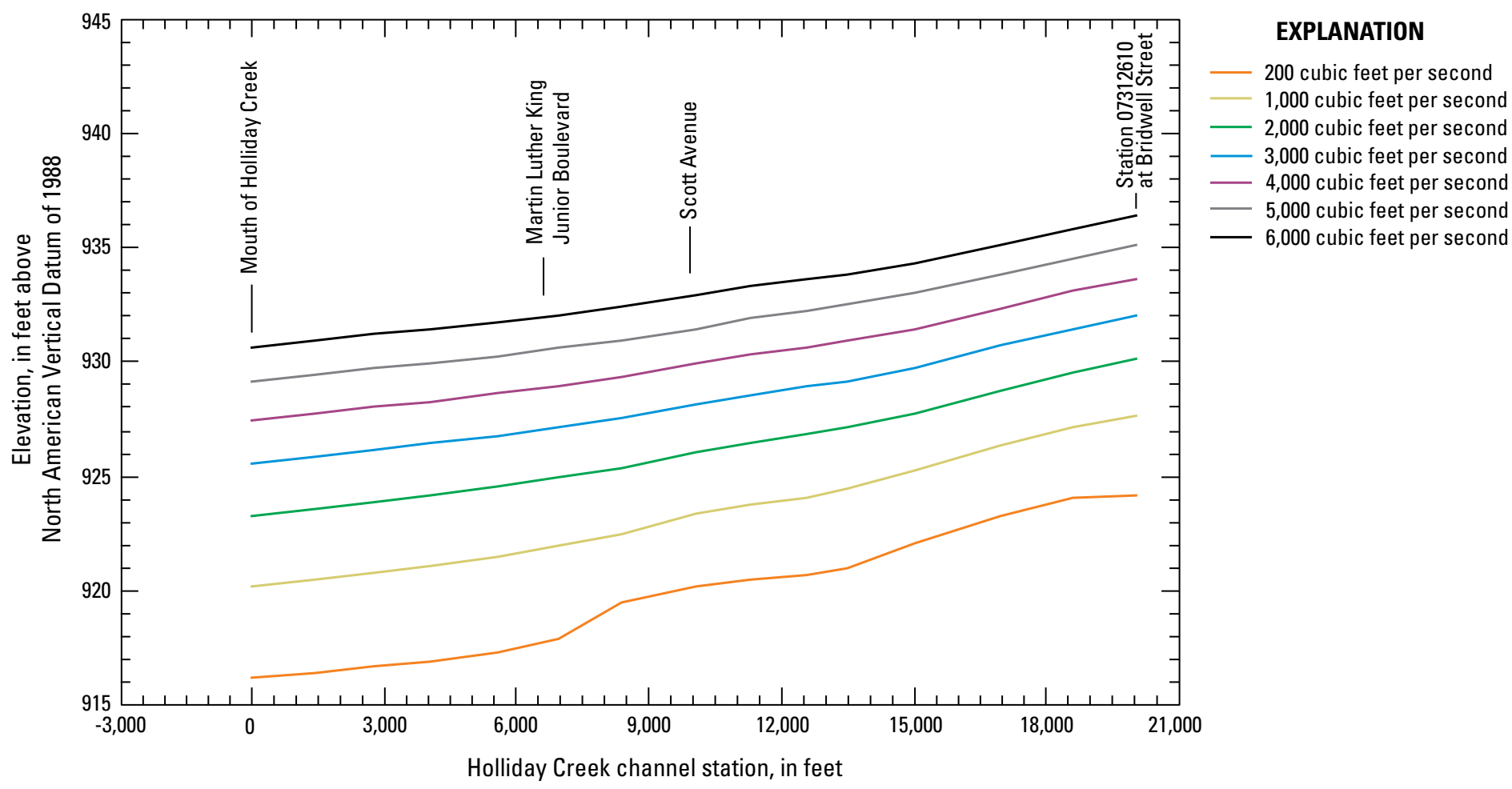

Figure 19. Water-surface profiles computed for various streamflow amounts in Holliday Creek, with no backwater from the Wichita River, Wichita Falls, Texas.

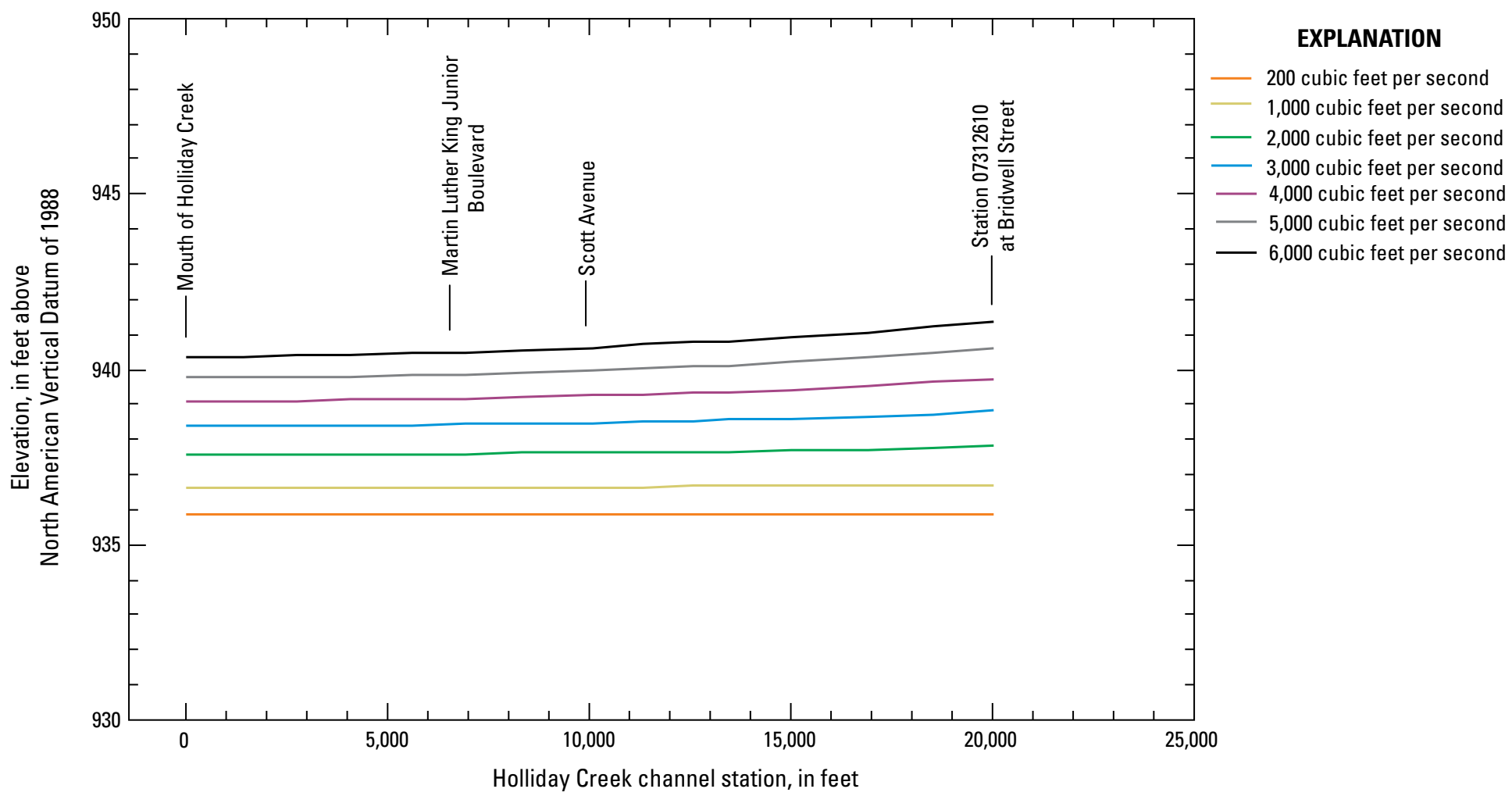

Figure 20. Water-surface profiles computed for various streamflow amounts in Holliday Creek, with backwater caused by streamflow of 10,100 cubic feet per second in the Wichita River (the 2007 flood peak), Wichita Falls, Texas. 


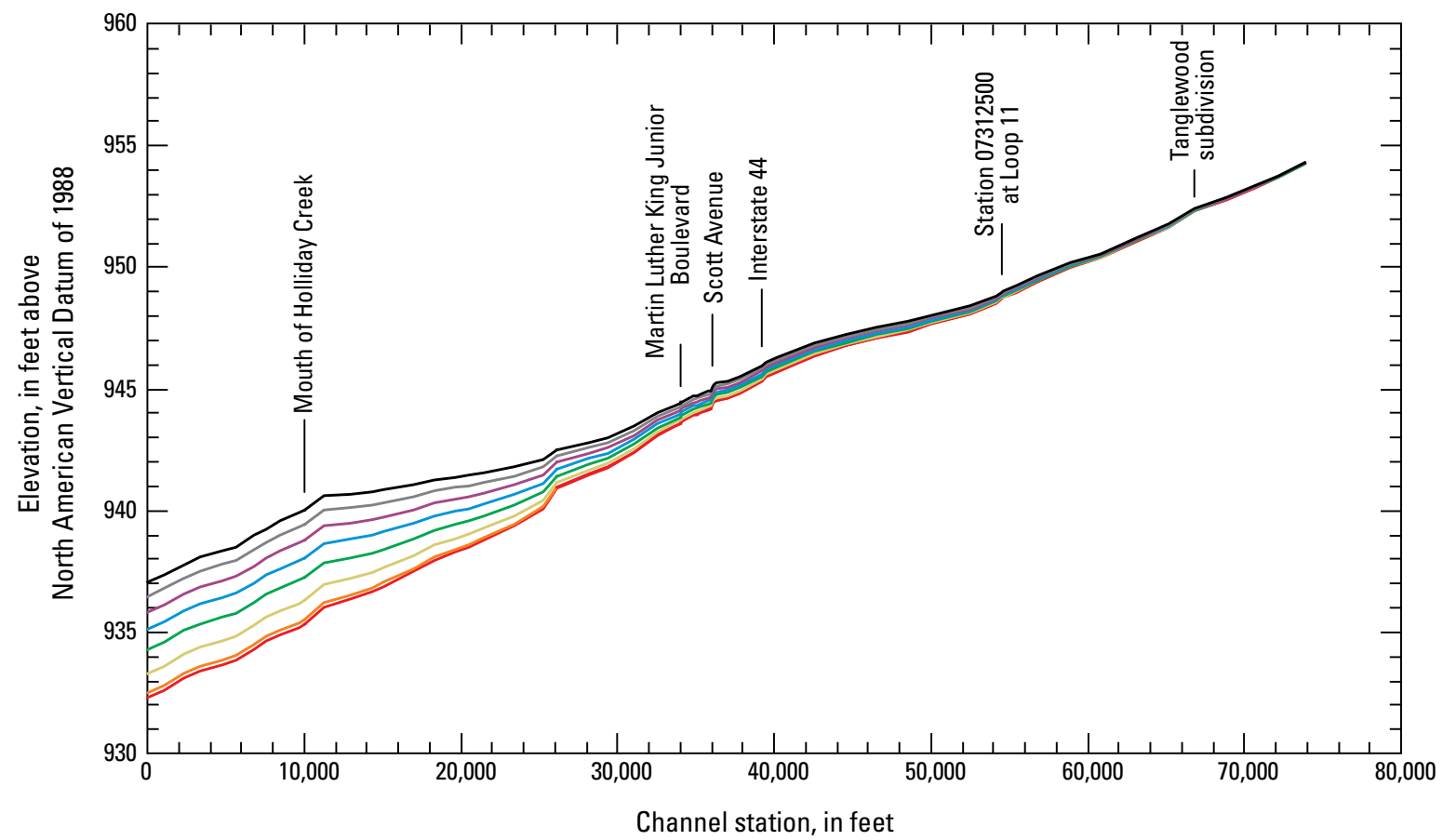

EXPLANATION
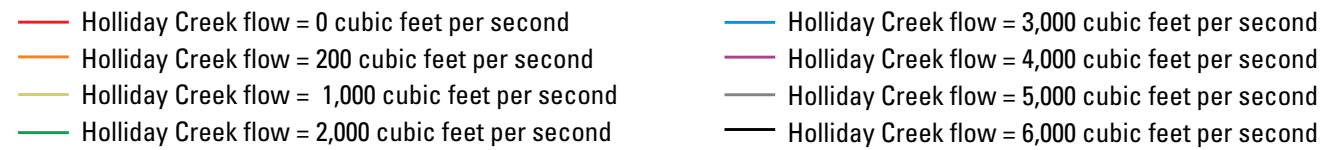

Figure 21. Computed water-surface profiles for streamflow of 10,100 cubic feet per second (the 2007 flood peak) in the Wichita River, with backwater caused by various streamflow amounts in Holliday Creek, Wichita Falls, Texas.

River and Holliday Creek. The effects of backwater decrease with distance upstream from the confluence (fig. 21). With $6,000 \mathrm{ft}^{3} / \mathrm{s}$ of flow in Holliday Creek, computed watersurface elevations for the 2007 flood on the Wichita River at Loop 11 were $0.27 \mathrm{ft}$ higher than those with no flow $\left(0 \mathrm{ft}^{3} / \mathrm{s}\right)$ in Holliday Creek.

\section{Flood Mitigation Alternatives}

Potential flood-mitigation alternatives were analyzed to determine what reduction in flood stages might be gained in response to each of several possible solutions. Four alternatives were considered:

1. Increasing capacity of the bypass channel - what if the entrance to the bypass channel (south of River Road) were deepened? Could enough flow be diverted from the main channel to substantially reduce flood stages upstream from the bypass channel?
2. Removing bridge obstructions - what if the obstructions were removed from the downstream side of Scott Avenue and Martin Luther King Junior Boulevard?

3. Widening aggraded channel banks - what if sections that have narrowed (as evidenced by the comparison of cross sections from the 1986 photogrammetric survey with those from the 2009 cross section survey by the U.S. Geological Survey) were widened to match those observed in 1986 ?

4. Reducing channel roughness - what if vegetation on the banks and overbanks was thinned by 20 or 50 percent?

To make side-by-side comparisons possible, each potential mitigation alternative was modeled using the 2007 flood-peak discharge $\left(10,100 \mathrm{ft}^{3} / \mathrm{s}\right)$. The results of each alternative scenario were compared with the calibrated 2007 flood profile, which was used to represent channel conditions as they existed in 2007. 


\section{Increasing Capacity on the Bypass Channel}

The bypass channel diverges from the Wichita River channel upstream from River Road (fig. 1). During large floods, the bypass carries flow away from the Wichita River on a steep and circuitous path and reenters the Wichita River immediately upstream from the mouth of Holliday Creek. In 2009, the elevation of the flow line (thalweg) of the bypass channel near its entrance was $938 \mathrm{ft}$, so the bypass only conveys flow when stages on the Wichita River exceed that elevation at the entrance to the bypass. The bypass channel did not flow during the 2008 flood. Flow in the bypass channel during the 2007 flood was computed to be $1,450 \mathrm{ft}^{3} / \mathrm{s}$ (14 percent of the total flow). Bypass channel flows were computed by determining what distribution of flow between the bypass and the Wichita River channel (north of the bypass) results in similar water-surface elevations (computed separately for both the Wichita River and the bypass channel by using the step-backwater model) at the inlet to the bypass channel.

The 2007 flood was modeled using two scenarios to assess the benefits of enlarging the entrance to the bypass channel by simulated channel excavations (cuts) to depths that were deeper by 4 and $8 \mathrm{ft}$. For each of these scenarios, the bypass channel was modeled using a $900-\mathrm{ft}$ long, trapezoidal (100-ft top width, 20 -ft bottom width) channel traversing a topographic high point along the bank of the Wichita River that controls flow into the bypass channel. First the cut was made to an elevation of $934 \mathrm{ft}$ ( $4 \mathrm{ft}$ below the existing flow line). The second cut was made to an elevation of $930 \mathrm{ft}(8 \mathrm{ft}$ below the existing flow line). Computed flood profiles for these two scenarios are shown in figure 22 . With the bypass channel cut to an elevation of $934 \mathrm{ft}$, computed water-surface elevations were reduced as much as $0.7 \mathrm{ft}$. With the bypass channel cut to an elevation of $930 \mathrm{ft}$, computed water-surface elevations were reduced as much as $1.4 \mathrm{ft}$. The greatest reduction occurs near the entrance to the bypass channel. Computed flows conveyed by the bypass channel are $2,500 \mathrm{ft}^{3} / \mathrm{s}$ ( 25 percent of the total flow) for the $934-\mathrm{ft}$ elevation and 3,500 $\mathrm{ft}^{3} / \mathrm{s}$ (35 percent of the total flow) for the $930-\mathrm{ft}$ elevation.

\section{Removing Bridge Obstructions}

The 2007 flood discharge was modeled with obstructions removed near the Scott Avenue and Martin Luther King

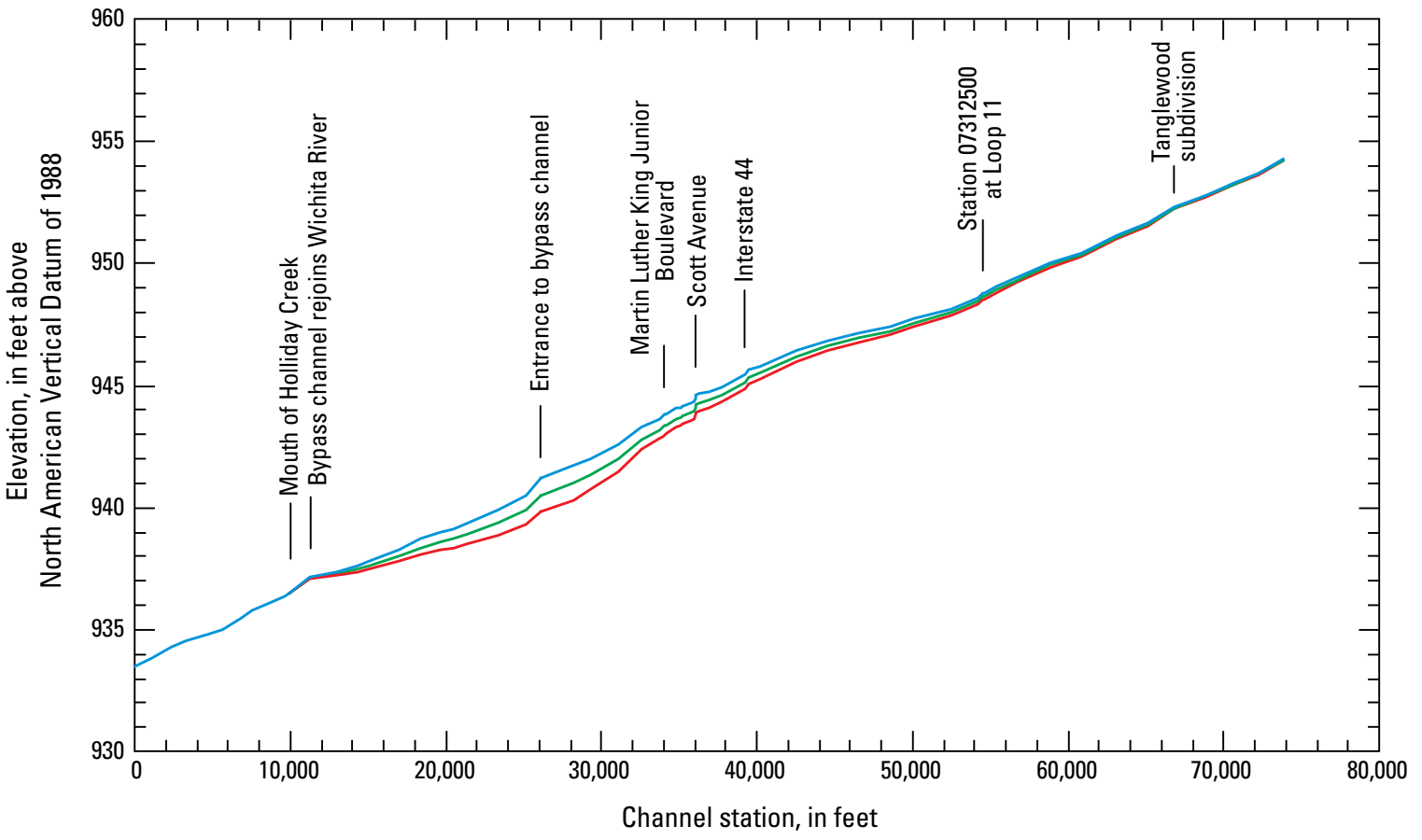

EXPLANATION

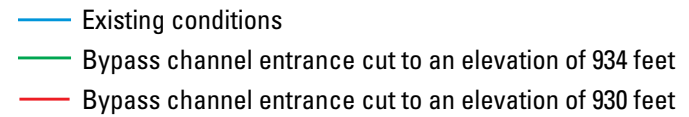

Figure 22. Computed water-surface profiles for streamflow of 10,100 cubic feet per second (the 2007 flood peak) in the Wichita River, with bypass channel cut deeper by 4 feet and 8 feet, Wichita Falls, Texas. 
Junior Boulevard bridges. The obstructed cross sections at the downstream side of each bridge were replaced with the section representing the unblocked bridge opening. Modeling the removal of the earth fill near these bridges (on the basis of the surveyed bridge-opening cross sections and the shape of the 2 -ft elevation contours) includes the following modifications to the step-backwater model: (1) $100 \mathrm{ft}$ downstream from Scott Avenue, remove ("cut") $20 \mathrm{ft}$ from the north banks and $30 \mathrm{ft}$ from the south bank; (2) $300 \mathrm{ft}$ downstream from Scott Avenue, "cut" $40 \mathrm{ft}$ from the north bank; and (3) $660 \mathrm{ft}$ upstream from Martin Luther King Junior Boulevard, "cut" $30 \mathrm{ft}$ from the north bank.

With the bridge obstructions removed from the cross sections, the modeled 2007 flood discharge yielded no reduction in water-surface elevation greater than $0.1 \mathrm{ft}$ at any location along the water-surface profile. A possible explanation for this is that most of the flow was conveyed by the main channel during the 2007 flood near the Scott Avenue and Martin Luther King Junior Boulevard bridges, so minor changes on the edge of the overbank had scant effects on water-surface elevations.

\section{Widening Aggraded Channel Banks}

The 2007 flood discharge was modeled with the aggraded channel banks (as surveyed in 2009, fig. 10) removed in the channel reach between 0.9 and $2.6 \mathrm{mi}$ downstream from Martin Luther King Junior Boulevard. On the basis of average channel characteristics in this part of the study reach for the 1986 and 2009 cross sections, the 2009 cross sections between 0.9 and 2.6 mi downstream from Martin Luther King Junior Boulevard were widened $40 \mathrm{ft}$ at the top of the flood channel and $20 \mathrm{ft}$ at the channel bed. The results of widening the channel downstream from Martin Luther King Junior Boulevard and removing obstructions near the Scott Avenue and Martin Luther King Junior Boulevard bridges are shown in figure 23. The greatest reduction in water-surface elevations was $1.1 \mathrm{ft}$, at the upstream end of the widened part of the reach near the Scott Avenue and Martin Luther King Junior Boulevard bridges.

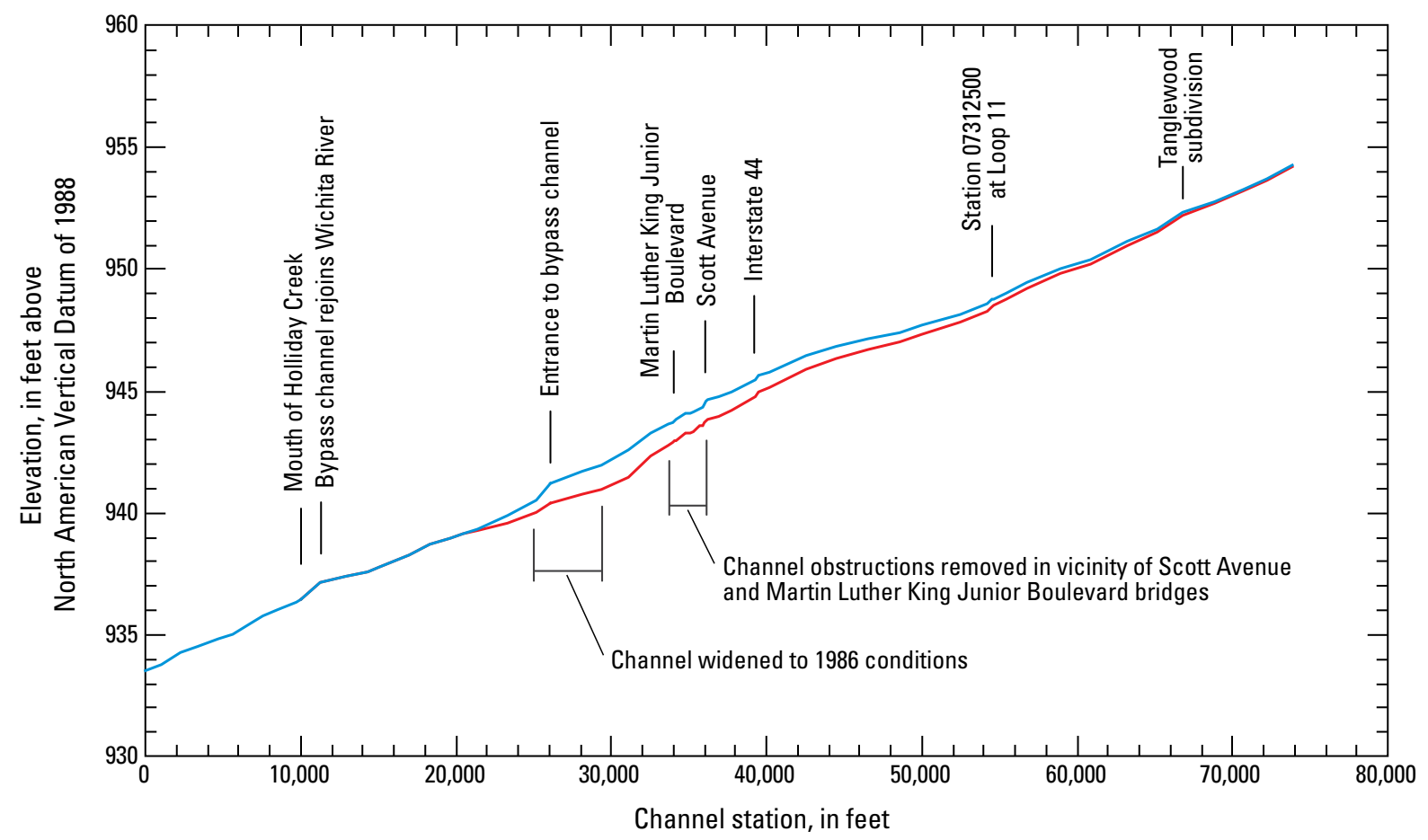

EXPLANATION

Existing conditions
Parts of Wichita River channel widened and obstructions
removed in vicinity of Scott Avenue and Martin Luther King
Junior Boulevard bridges

Figure 23. Computed water-surface profiles for streamflow of 10,100 cubic feet per second (the 2007 flood peak) in the Wichita River, with parts of the channel widened and obstructions near Scott Avenue and Martin Luther King Junior Boulevard bridges removed, Wichita Falls, Texas. 


\section{Reducing Channel Roughness}

The 2007 flood discharge was modeled using two scenarios with different Manning's $n$ values representing different degrees of brush thinning on the channel banks and overbanks. In the first scenario, 20 percent of the vegetation was removed from the channel banks and overbank areas throughout the study reach. In the second scenario, 50 percent of the vegetation was removed.

The vegetation-density method (Arcement and Schneider, 1989; Petryk and Bosmajian, 1975) can be used for estimating Manning's $n$ for a given area on the flood plain on the basis of the number of trees of specified diameters growing in that part of the flood plain. Typically the method is used to estimate an unknown roughness, but the method can be "reverse engineered" to calculate a vegetation density for a given Manning's $n$ value. Figure 24 shows the vegetation for a segment of the overbank downstream from the Loop 11 gage when the leaves are off the trees. Tree counts for five tree-diameter classes in increments of $0.1 \mathrm{ft}$ between $0.1 \mathrm{ft}$ and $0.5 \mathrm{ft}$ were estimated for a selected area of the overbank in the photograph. To determine Manning's roughness coefficient with less vegetation, the tree counts were reduced (proportionally for each class), and the corresponding roughness was computed. Figure 25 shows the resulting reduction in Manning's roughness coefficient corresponding to a reduction in vegetation ranging from 0 to 100 percent of 2010 vegetation. Note that the curve in figure 25 is based on a uniform tree-count distribution across all classes, and a base Manning's $n$ of 0.032 for a channel with no vegetation (Arcement and Schneider, 1989, p. 4). The curve is not transferable to other applications; it is a tool to approximate

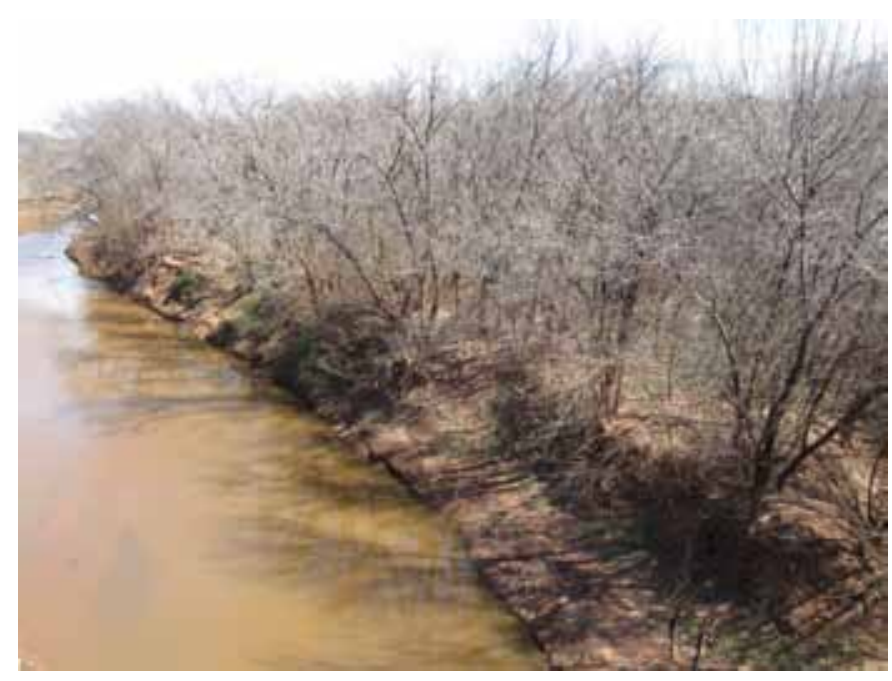

Figure 24. Looking downstream from Loop 11 at the U.S. Geological Survey streamflow-gaging station 07312500 Wichita River at Wichita Falls, Texas, February 25, 2009.

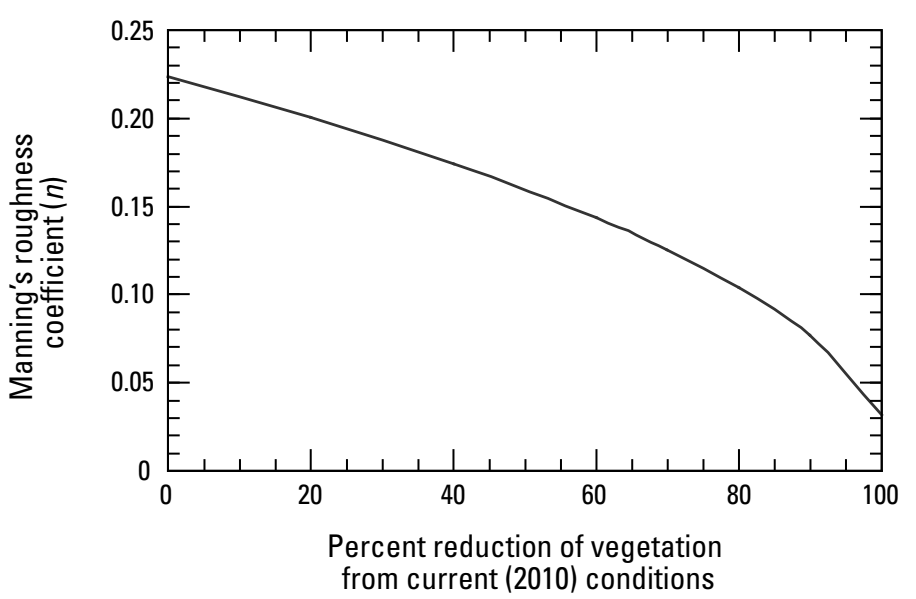

Figure 25. Reduction in Manning's roughness coefficient $(n)$ corresponding to a reduction in channel-bank and flood-plain vegetation, Wichita River at Wichita Falls, Texas.

the relation between vegetation density and Manning's $n$ for the Wichita River at Wichita Falls, Tex. From figure 25, the Manning's $n$ corresponding to a 20-percent reduction of vegetation is 0.20 (a 9-percent reduction in the roughness coefficient); the Manning's $n$ corresponding to a 50-percent reduction in vegetation is 0.16 (a 27-percent reduction in roughness). Finally, the 2007 flood discharge is modeled for a 20-percent and a 50-percent reduction in vegetation. For a 20-percent reduction in vegetation, computed flood stages were reduced as much as $1.0 \mathrm{ft}$ and, on average (for the entire modeled reach), $0.9 \mathrm{ft}$. For a 50-percent reduction in vegetation, computed flood stages were reduced as much as $3.0 \mathrm{ft}$ and, on average, $2.6 \mathrm{ft}$ (fig. 26).

The density of vegetation on the overbank during the 1941 flood was estimated by applying the calibrated overbank roughness coefficient (table 2) to the curve in figure 25. An overbank roughness of 0.064 indicates that vegetation might have been about 90 percent less in 1941 than in 2010 (fig. 25). Photographs of the channel indicate substantial vegetation growth occurred on the channel banks between 1950 and 2009 (fig. 7).

\section{Comparison of Flood Mitigation Alternatives}

Comparisons of the computed flood profiles between various mitigation alternatives are difficult, primarily because of the arbitrary degree to which each alternative was applied in the modeling scenarios. For example, a 4-ft and an 8-ft cut were modeled for the bypass channel. Why not $12 \mathrm{ft}$ ? Similar questions can be raised for the other modeled flood-mitigation alternatives. 


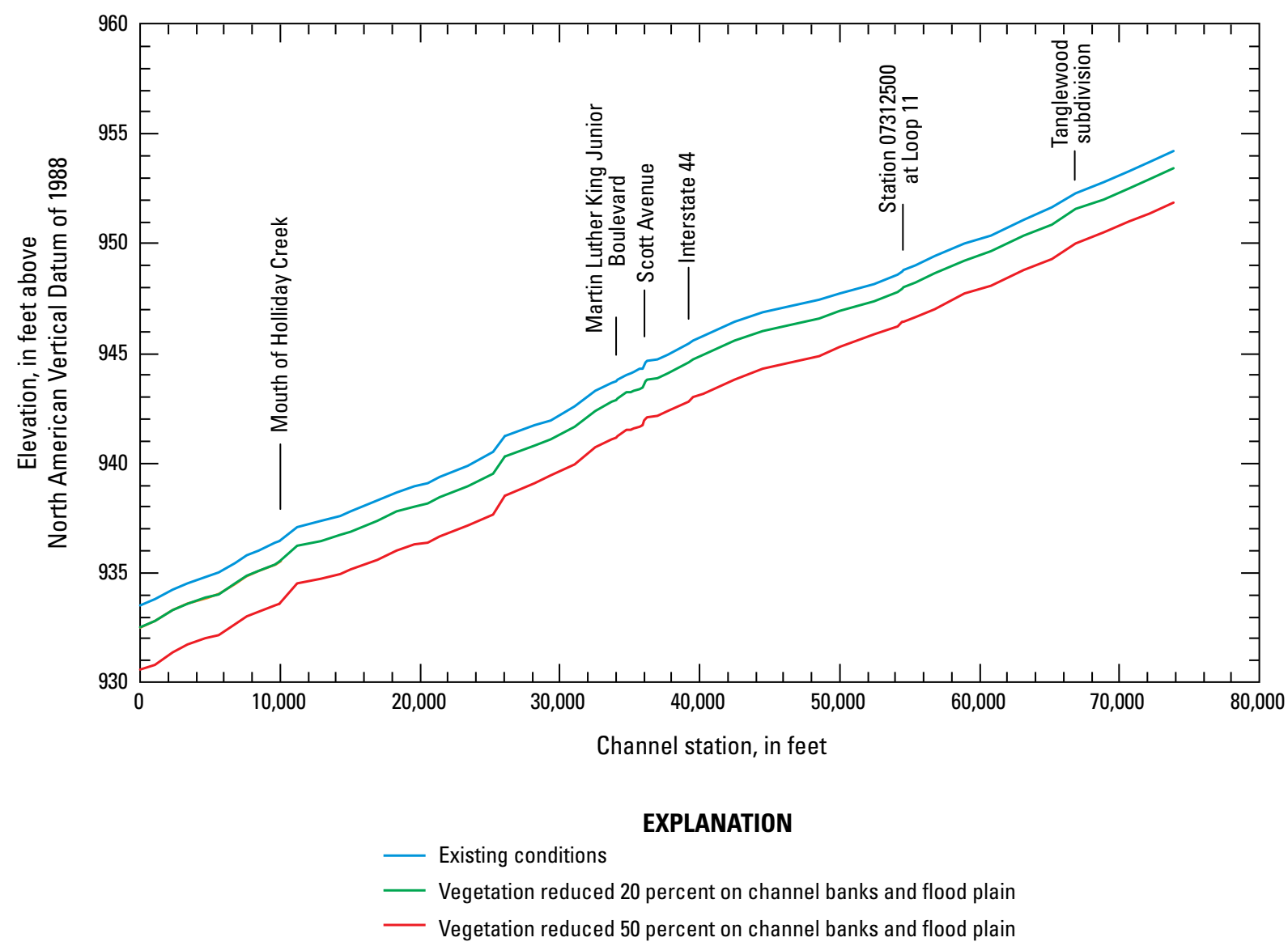

Figure 26. Water-surface profiles computed for streamflow of 10,100 cubic feet per second (the 2007 flood) in the Wichita River, with vegetation reduced 20 and 50 percent on the channel banks and flood plain, Wichita Falls, Texas.

In general, deepening the upper reaches of the bypass channel yielded the greatest reduction in flood stage immediately upstream from the entrance to the bypass. The $4-\mathrm{ft}$ cut resulted in as much as a 0.8 - $\mathrm{ft}$ reduction in flood stage at the upstream end of the bypass channel; the 8 -ft cut resulted in as much as a $1.4-\mathrm{ft}$ reduction in flood stage at the upstream end of the bypass channel. This reduction is less at locations further upstream or downstream from the entrance to the bypass channel (fig. 22). The 4-ft bypass cut results in less than a $0.1-\mathrm{ft}$ reduction at the Tanglewood subdivision (fig. 22). Computed water-surface elevations for various flood-mitigation alternatives are presented along with those for existing (2010) conditions in table 5.

Widening the narrowed segment of the channel between Martin Luther King Junior Boulevard and River Road and removing fill near the Scott Avenue and Martin Luther King Junior Boulevard bridges yielded as much as a $1.1-\mathrm{ft}$ reduction in flood elevation, with the maximum reduction at the upstream end of the widened part of the reach (fig. 23). Reductions in flood elevation computed for this scenario translate upstream somewhat, with a $0.7-\mathrm{ft}$ reduction at
Interstate Highway 44. However, the reduction in flood elevation is only about $0.3 \mathrm{ft}$ at Loop 11 .

The final potential flood-mitigation alternative is the thinning of channel bank and flood-plain vegetation to reduce Manning's $n$. Without thinning, Manning's $n$ was as large as 0.22 in the roughest areas of the flood plain, the densely vegetated banks and overbanks. A 20-percent reduction in riparian vegetation on the banks and overbanks resulted in a 9-percent reduction in Manning's $n$. A 50-percent reduction in riparian vegetation resulted in a 27 -percent reduction in Manning's $n$. The 2007 flood discharge was modeled using these reduced roughness coefficients. For a 20-percent reduction in riparian vegetation, mean reduction in flood elevation was about $0.9 \mathrm{ft}$. For a 50-percent reduction in riparian vegetation, mean reduction in flood elevation was about $2.6 \mathrm{ft}$. These values represent thinning of vegetation throughout the model; for areas left in their current (2011) state, flood elevations might deviate from these results.

The effects of implementing a combination of different flood-mitigation alternatives were not investigated. Although the reduction in flood elevations achieved through a 
Table 5. Computed water-surface elevations for 10,100 cubic feet per second (the peak discharge of the 2007 flood) on the Wichita River at Wichita Falls, Texas, for existing (2010) channel conditions and various flood-mitigation alternatives

\begin{tabular}{|c|c|c|c|c|c|c|}
\hline \multirow[b]{2}{*}{$\begin{array}{c}\text { Location } \\
\text { (fig. 1) }\end{array}$} & \multicolumn{6}{|c|}{ Computed water-surface elevation, in feet above North American Vertical Datum of 1988} \\
\hline & $\begin{array}{l}\text { Existing } \\
\text { channel } \\
\text { conditions }\end{array}$ & $\begin{array}{c}\text { 4-foot } \\
\text { bypass cut }\end{array}$ & $\begin{array}{c}\text { 8-foot } \\
\text { bypass cut }\end{array}$ & $\begin{array}{c}\text { Widening of } \\
\text { narrowed sections }\end{array}$ & $\begin{array}{c}20 \text { percent } \\
\text { vegetation } \\
\text { reduction }\end{array}$ & $\begin{array}{c}50 \text { percent } \\
\text { vegetation } \\
\text { reduction }\end{array}$ \\
\hline River Road & 937.58 & 937.46 & 937.35 & 937.58 & 936.68 & 934.94 \\
\hline $\begin{array}{l}\text { Martin Luther King } \\
\text { Junior Boulevard }\end{array}$ & 943.77 & 943.33 & 942.96 & 942.95 & 942.91 & 941.21 \\
\hline Scott Avenue & 944.46 & 944.08 & 943.76 & 943.68 & 943.60 & 941.91 \\
\hline Interstate Highway 44 & 945.42 & 945.10 & 944.84 & 944.73 & 944.54 & 942.79 \\
\hline Loop 11 & 948.73 & 948.60 & 948.50 & 948.46 & 947.96 & 946.43 \\
\hline Tanglewood subdivision & 952.29 & 952.24 & 952.20 & 952.18 & 951.55 & 950.00 \\
\hline Fort Worth-Denver Railroad & 954.23 & 954.20 & 954.18 & 954.17 & 953.45 & 951.85 \\
\hline
\end{tabular}

combination of mitigation alternatives might be greater than the reduction from any one remedy alone, the combined effects of individual mitigation alternatives might not be strictly cumulative.

\section{Summary}

Continuous records of stage and discharge have been made at U.S. Geological Survey (USGS) streamflow-gaging station 07312500 Wichita River at Wichita Falls, Texas, since 1938. A record stage (since at least 1938) of 24.40 feet (ft) with a peak discharge of 10,100 cubic feet per second $\left(\mathrm{ft}^{3} / \mathrm{s}\right)$ was recorded on June 30, 2007. On August 19, 2008, a flood stage of $20.51 \mathrm{ft}$ with a peak discharge of $6,940 \mathrm{ft}^{3} / \mathrm{s}$ was recorded at USGS streamflow-gaging station 07312500. Understanding the causes for increased flood stages on the Wichita River in 2007 and 2008 floods compared to flood stages during floods of similar or smaller magnitude prior to 1972 is important to water resource managers in Texas. The reliability of annual peak-streamflow data for USGS streamflow-gaging station 07312500 requires an understanding of the factors affecting stream stage on the Wichita River. The USGS, in cooperation with the City of Wichita Falls, assessed channel changes on the Wichita River in Wichita Falls, and modeled historical floods to investigate possible causes and potential mitigation alternatives to reduce flood elevations such as those experienced in recent (2007 and 2008) floods.
Streamflow records during 1938-2007 at streamflowgaging station 07312500 indicate seven or eight floods roughly similar (or greater) in magnitude than the $10,100 \mathrm{ft}^{3} / \mathrm{s}$ peak discharge of the 2007 flood. Although the peak discharges of floods prior to 2007 were of similar or greater magnitude compared to the 2007 flood, none of the floods since 1938 reached the stage of the 2007 flood. Data from three USGS streamflow-gaging stations were used to assess channel changes and evaluate flood-mitigation alternatives. In addition to data from streamflow-gaging station 07312500 , data from USGS streamflow-gaging stations 07312610 Holliday Creek at Wichita Falls, Tex., and 07312700 Wichita River near Charlie, Tex., were used in this study. Streamflow-gaging station 07312610 Holliday Creek at Wichita Falls, Tex., is located at Bridwell Street about 3.7 (mi) upstream from the mouth of Holliday Creek. The more than 1,000 discharge measurements made at streamflow-gaging station 07312500 Wichita River at Wichita Falls, Tex., during 1938-2010 indicate no substantial aggradation has occurred on the channel bed or banks near Loop 11. Discharge measurements for stages of more than $18 \mathrm{ft}$ from 1938 to 2008 indicate a decrease in the measured mean velocity from about 3.5 feet per second ( $\mathrm{ft} / \mathrm{s})$ in 1941 to about $2.0 \mathrm{ft} / \mathrm{s}$ in 2008 . This reduction in velocity was accompanied by an increase in stage to convey similar discharges through the system.

Aerial and ground photographs were analyzed to determine an increase in vegetation in the channel or overbank in the reach of the river near the gage contributed to the 
elevated flood stages in 2007 and 2008 compared to historical flood stages for similar flood discharges. Since 1950, oblique photographs of the Wichita River channel at Loop 11 have been taken periodically by personnel of the USGS. The aerial photographs indicate an increase in vegetation between 1953 and 1991 along the banks and in the flood plain at Lucy Park, 1 to 2 mi downstream from Loop 11. Ground photographs taken near Loop 11 in 1950, 1961, 1975, and 2009 indicate a substantial amount of riparian vegetation growth occurred between 1950 and 2009.

Channel cross sections at Loop 11 at streamflow-gaging station 07312500 Wichita River at Wichita Falls, Tex., during 1938-2009 indicate that, while minor changes in crosssection shape are observed, the thalweg and the width of the channel are fairly stable. Cross sections surveyed in 2009 by the USGS between Loop 11 and River Road compared favorably with those from a 1986 photogrammetric survey. However, four consecutive cross sections located between 0.9 and 2.6 mi downstream from Martin Luther King Junior Boulevard indicated substantial narrowing. For those four cross sections, the loss in channel width was typically 30 to $50 \mathrm{ft}$. Comparison of the 2009 surveys of the channels to bridge openings shown on as-built bridge plans indicates no change in cross section. Obstructions were noted at the downstream side of the Scott Avenue bridge (south span) and at the Martin Luther King Junior bridge (north span), which only partially block flow but could reduce channel conveyance during floods.

The floods of 2007, 2008, and 1941 were modeled using a one-dimensional, steady-state, step-backwater model developed by the USGS for the Wichita River in Wichita Falls in order to prepare a calibrated model useful for modeling different flood-mitigation alternatives (the 1941 flood is used for comparison with the 2007-8 floods because the channel in 1941 was different compared to the channel in 2007 and 2008). Calibration of the 2007 and 2008 floods was done by adjusting Manning's $n$ so that differences in computed and observed water-surface elevations at the Loop 11 gage and the staff gages were minimized. Calibration of the model to the June 2007 flood indicated Manning's $n$ was as large as 0.22 in the roughest areas of the flood plain and 0.048 in the Wichita River channel. The relatively large calibrated roughness values for the June 2007 flood are indicative of a densely vegetated flood plain and a rougher-than-average natural channel. Calibration of the August 2008 flood indicated flood-plain roughness as large as 0.22 in the roughest areas of the flood plain, but the Wichita River channel roughness was 0.041. The difference between the 2007 and 2008 calibrated Manning's $n$ for the Wichita River channel could be because of the 4-ft stage difference between the two floods and the increased effect of overhanging branches at higher stages. The October 3, 1941, flood peaked at $24.00 \mathrm{ft}$ at streamflow-gaging station 07312500 Wichita River at Wichita Falls, Tex., with a discharge of $17,800 \mathrm{ft}^{3} / \mathrm{s}$. The calibrated Manning's $n$ for the Wichita River for the 1941 flood is 0.030 , which is a relatively small value for a natural channel, indicating that the channel conveyed flow more efficiently in 1941 than in 2007.

A large inflow from Holliday Creek can cause backwater on the Wichita River, and large flows in the Wichita River can cause backwater on Holliday Creek. During low-flow conditions, the streams often act independently of each other and there is no relation between the stage on one stream and the stage on the other stream. Eight concurrent rises on Wichita River and Holliday Creek were analyzed to determine the timing of peaks on the two streams and to assess the degree to which each was affected by backwater. Based on analysis of the storm hydrographs from the 2010 water year, the Wichita River at Loop 11 typically peaks about 34 hours after Holliday Creek. However, the lag varied from as little as 7 hours to as much as 44 hours. Holliday Creek was observed by USGS personnel to be flowing at the peak of the 2007 flood recorded at the Loop 11 gage, corroborating the possibility that the peaks from Wichita River and Holliday might have peaked concurrently during the 2007 flood.

The 2010 step-backwater model was used to assess the potential extent of backwater during flooding at the confluence of Wichita River and Holliday Creek. Flood profiles were computed for Holliday Creek without backwater and in backwater conditions; the backwater conditions simulated the conditions likely to have occurred during the large 2007 flood. Channel roughness for Holliday Creek was calibrated on the basis of the April 19, 2010, measured discharge of 1,220 ft $3 / \mathrm{s}$ at a stage of $8.90 \mathrm{ft}(928.51 \mathrm{ft}$ above North American Vertical Datum of 1988) at the Holliday Creek gage. The calibrated Manning's $n$ for Holliday Creek is 0.031 . The effects of flows ranging from 0 to $6,000 \mathrm{ft}^{3} / \mathrm{s}$ in Holliday Creek on watersurface elevation were modeled for the Wichita River. With $6,000 \mathrm{ft}^{3} / \mathrm{s}$ of streamflow in Holliday Creek, computed watersurface elevations for the 2007 flood on the Wichita River at Loop 11 were $0.27 \mathrm{ft}$ higher than with no streamflow $\left(0 \mathrm{ft}^{3} / \mathrm{s}\right)$ in Holliday Creek.

Potential flood-mitigation alternatives were analyzed to determine what reduction in flood stages might be gained in response to each of several possible solutions. Four scenarios were considered: increasing capacity of the bypass channel, removing bridge obstructions, widening aggraded channel banks, and reducing channel roughness. To make side-by-side comparisons possible, each potential mitigation alternative was modeled using the 2007 flood-peak discharge.

In the first flood-mitigation alternative, the bypass channel was modeled as being deeper by different amounts. In 2009, the elevation of the flow line (thalweg) of the bypass channel near its entrance was $938 \mathrm{ft}$, so the bypass only conveys flow when stages on the Wichita River exceed that elevation at the entrance to the bypass. With the bypass cut to an elevation of $934 \mathrm{ft}$, computed water-surface elevations were reduced as much as $0.7 \mathrm{ft}$. With the bypass channel cut to an elevation of $930 \mathrm{ft}$, computed water-surface elevations were reduced as much as $1.4 \mathrm{ft}$. The greatest reduction in water-surface elevation occurs near the entrance to the bypass channel. In the second flood-mitigation alternative, 
bridge obstructions removed near Martin Luther King Junior Boulevard and Scott Avenue bridges were removed in the model. No reductions in water-surface elevation greater than $0.1 \mathrm{ft}$ were computed at any location along the watersurface profile for 2007 flood. In the third flood-mitigation alternative, aggraded channel banks between 0.9 and $2.6 \mathrm{mi}$ downstream from Martin Luther King Junior Boulevard were removed from the channel reach. The greatest reduction in water-surface elevations was $1.1 \mathrm{ft}$ at the upstream end of the widened part of the reach near the Scott Avenue and Martin Luther King Junior Boulevard bridges. In the fourth floodmitigation alternative, two Manning's $n$ values representing different degrees of brush thinning on the channel banks and overbanks ( 20 and 50 percent thinning of the vegetation removed from the channel banks and overbank areas throughout the study reach) were modeled. A 20-percent reduction in vegetation results in a Manning's $n$ of 0.20 for the banks and overbanks, a 9-percent reduction from the Manning's $n$ of 0.22 (determined without any thinning). For a 20-percent reduction in vegetation, computed flood stages were reduced as much as $1.0 \mathrm{ft}$, and on average by $0.9 \mathrm{ft}$. A 50-percent reduction in vegetation results in a Manning's $n$ of 0.16 (a 27-percent reduction in roughness). For a 50-percent reduction in vegetation, computed flood stages were reduced by as much as $3.0 \mathrm{ft}$ and on average were reduced by $2.6 \mathrm{ft}$. The calibrated overbank roughness during the 1941 flood was 0.064 . This indicates that vegetation might have been about 90 percent less in 1941 compared to 2010. The effects of implementing a combination of different flood-mitigation alternatives were not investigated. Although the reduction in flood elevations achieved through a combination of mitigation alternatives might be greater than any one remedy alone, the combined effects of individual mitigation alternatives might not be strictly cumulative.

\section{References Cited}

Arcement, G.J., Jr., and Schneider, V.R., 1989, Guide for selecting Manning's roughness coefficients for natural channels and flood plains: U.S. Geological Survey Water-Supply Paper 2339, 38 p.

Barnes, H.H., Jr., 1967, Roughness characteristics of natural channels: U.S. Geological Survey Water-Supply Paper 1849, $213 \mathrm{p}$.

Brunner, G. W., 2008, HEC-RAS, River Analysis System user's manual: U.S. Army Corps of Engineers Hydrologic Engineering Center, 733 p.

Brunner, G. W., 2010, HEC-RAS, River Analysis System hydraulic reference manual: U.S. Army Corps of Engineers Hydrologic Engineering Center, 411 p.

Chow, Ven Te, 1959, Open-channel hydraulics: New York, McGraw-Hill, $680 \mathrm{p}$.
Collier, Michael, Webb, R.H., and Schmidt, J.C., 1996, Dams and rivers - A primer on the downstream effects of dams: U.S. Geological Survey Circular 1126, 94 p.

Davidian, Jacob, 1984, Computation of water-surface profiles in open channels: U.S. Geological Survey Techniques of Water-Resources Investigations, book 3, chap. A15, 48 p.

Federal Emergency Management Agency, 2000, Flood insurance study, City of Wichita Falls, Texas.

Federal Emergency Management Agency, 2010, Flood insurance rate map, Wichita County, Texas, and incorporated areas, accessed February 1, 2011, at http://msc.fema.gov/.

Federal Emergency Management Agency, 2011, Mitigation best practices-Public and private sector best practice stories for all activity/project types in all states and territories relating to all hazards: accessed September 20, 2011, at http://www.fema.gov/mitssdata/ BestPracticesAndCaseStudies.pdf.

Heitmuller, F.T., and Greene, L.E., 2009, Historical channel adjustment and estimates of selected hydraulic values in the lower Sabine River and lower Brazos River Basins, Texas and Louisiana: U.S. Geological Survey Scientific Investigations Report 2009-5174, 143 p.

Holmes, R.R., Jr., and Dinicola, K., 2010, 100-Year floodIt's all about chance: U.S. Geological Survey General Information Product 106, 1 p.

Koogle and Pouls Engineering, 1986, Aerial maps, Wichita Falls, Texas: Flown in March 1986, scales 1:2,400 and $1: 7,200$, contour interval 2 feet.

Langbein, W.B., and Iseri, K.T., 1960, General introduction and hydrologic definitions: U.S. Geological Survey Water-Supply Paper 1541-A, 29 p.

Linsley, R.K., Kohler, M.A., and Paulhus, J.L.H., 1982, Hydrology for engineers ( $3 \mathrm{~d}$ ed.): New York, McGraw-Hill, 512 p.

Missouri Department of Transportation, 2011, Engineering policy guide-Structure and hydraulics: accessed September 15, 2011, at http://epg.modot.org/index. php?title=748.4_Headwater_and_Backwater.

Petryk, Sylvester, and Bosmajian, George, III, 1975, Analysis of flow through vegetation: Proceedings, American Society of Civil Engineers, Journal of the Hydraulics Division, v. 101, no. HY7, p. 871-884.

Red River Authority of Texas, 2011, Basin summary reportRed River Basin, reach II: accessed September 28, 2011, at http://www.rra.dst.tx.us/publications/CRP/crp2004/Red BSR_files/WATSUM/REACH3/..\%5C..\%5CWATSUM $\% 5$ Creach2\%5Cdefault.cfm. 
Rantz, S.E., and others, 1982, Measurement and computation of streamflow-v. 1, Measurement of stage and discharge: U.S. Geological Survey Water-Supply Paper 2175, 283 p.

Shafroth, P.B., Stromberg, J.C., and Patten, D.T., 2002, Riparian vegetation response to altered disturbance and stress regime: Ecological Applications, v. 12, no. 1, p. 107-123, accessed January 28, 2010, at http://www.esajournals.org/doi/abs/10.1890/10510761(2002)012\%5B0107:RVRTAD\%5D2.0.CO\%3B2.

Trimble, 2009, Trimble R4 GPS System Data Sheet, accessed August 16, 2010, at http://trl.trimble.com/ docushare/dsweb/Get/Document-468267/022543-490A_ TrimbleR4_DS_1109_LR.pdf.

U.S. Army Corps of Engineers, 1987, Corps of Engineers wetlands delineation manual: Wetlands Research Program Technical Report Y-87-1, 143 p., accessed September 22, 2011, at http://el.erdc.usace.army.mil/ elpubs/pdf/wlman87.pdf.

U.S. Army Corps of Engineers, 2010, HEC-RAS: accessed February 2010 at http://www.hec.usace.army.mil/software/ hec-ras/.

U.S. Geological Survey, 2010, National Water Information System: accessed November 2010 at http://waterdata.usgs. gov/tx/nwis/.

Winters, K.E., Baldys, S. III, and Schreiber, R., 2010, Reduced channel conveyance on the Wichita River at Wichita Falls, Texas, 1900-2009: Journal of Environmental Hydrology, v. 18, 11 p, accessed September 7, 2011, at http://www. hydroweb.com/protect/pubs/jeh/jeh2010/winters.pdf. 


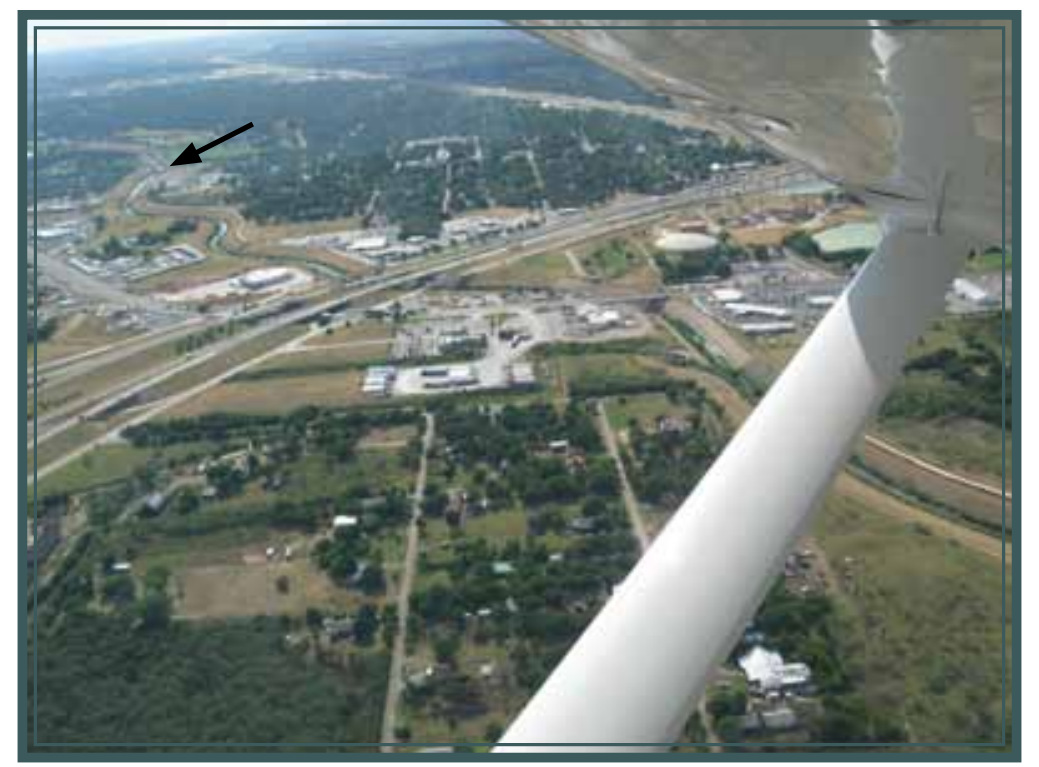

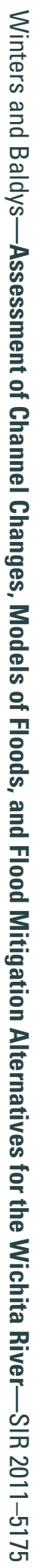

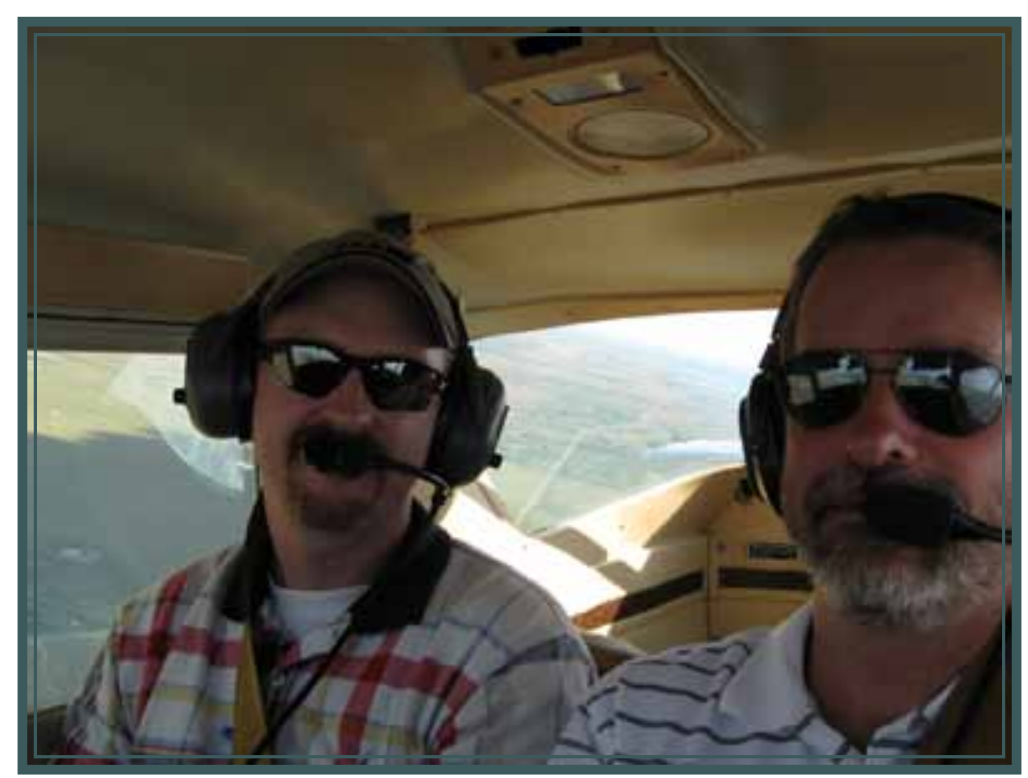

